\title{
Seasonal and diurnal variations of particulate nitrate and organic matter at the IfT research station Melpitz
}

\author{
L. Poulain ${ }^{1}$, G. Spindler ${ }^{1}$, W. Birmili ${ }^{1}$, C. Plass-Dülmer ${ }^{2}$, A. Wiedensohler ${ }^{1}$, and H. Herrmann ${ }^{1}$ \\ ${ }^{1}$ Leibniz-Institut für Troposphärenforschung (IfT), Leipzig, Germany \\ ${ }^{2}$ German Weather Service, Hohenpeissenberg, Germany
}

Received: 30 March 2011 - Published in Atmos. Chem. Phys. Discuss.: 13 April 2011

Revised: 16 November 2011 - Accepted: 18 November 2011 - Published: 15 December 2011

\begin{abstract}
Ammonium nitrate and several organic compounds such as dicarboxylic acids (e.g. succinic acid, glutaric acid), some Polycyclic Aromatic Hydrocarbon (PAHs) or some $n$-alkanes are semi-volatile. The transition of these compounds between the gas and particulate phase may significantly change the aerosol particles radiative properties, the heterogeneous chemical properties, and, naturally, the total particulate mass concentration. To better assess these time-dependent effects, three intensive field experiments were conducted in 2008-2009 at the Central European EMEP research station Melpitz (Germany) using an Aerodyne Aerosol Mass Spectrometer (AMS). Data from all seasons highlight organic matter as being the most important particulate fraction of $\mathrm{PM}_{1}$ in summer (59\%) while in winter, the nitrate fraction was more prevalent $(34.4 \%)$. The diurnal variation of nitrate always showed the lowest concentration during the day while its concentration increased during the night. This night increase of nitrate concentration was higher in winter $\left(\Delta \mathrm{NO}_{3}^{-}=3.6 \mu \mathrm{g} \mathrm{m}^{-3}\right)$ than in sum$\operatorname{mer}\left(\Delta \mathrm{NO}_{3}^{-}=0.7 \mu \mathrm{g} \mathrm{m}^{-3}\right)$. The variation in particulate nitrate was inherently linked to the gas-to-particle-phase equilibrium of ammonium nitrate and the dynamics of the atmosphere during day. The results of this study suggest that during summer nights, the condensation of $\mathrm{HNO}_{3}$ and $\mathrm{NH}_{3}$ on pre-existing particles represents the most prevalent source of nitrate, whereas during winter, nighttime chemistry is the predominant source of nitrate. During the summer 2008's campaign, a clear diurnal evolution in the oxidation state of the organic matter became evident (Organic Mass to Organic Carbon ratio $(O M / O C)$ ranging from 1.65 during night to 1.80 during day and carbon oxidation state $(\mathrm{OSc})$ from -0.66 to -0.4$)$, which could be correlated to hydroxyl radical $(\mathrm{OH})$ and ozone concentrations, indicating a photochemical trans-
\end{abstract}

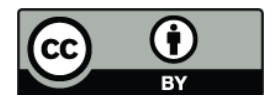

Correspondence to: H. Herrmann (herrmann@tropos.de) formation process. In summer, the organic particulate matter seemed to be heavily influenced by regional secondary formation and transformation processes, facilitated by photochemical production processes as well as a diurnal cycling of the substances between the gas and particulate phase. In winter, these processes were obviously less pronounced (OM/OC ranging from 1.60 to 1.67 and OSc from -0.8 to -0.7 ), so that organic matter apparently originated mainly from aged particles and long range transport.

\section{Introduction}

Due to their influence on cloud formation, visibility, light scattering, and light absorption (IPCC, 2007), atmospheric aerosol particles are known to have important direct and indirect effects on earth climate. Moreover, aerosol particles can also affect ecosystems (e.g. Bohlmann et al., 2005; Jickells et al., 2005) and - upon interaction with the respiratory and cardiovascular systems - human mortality and morbidity (e.g. Pope, 2000; Ostro et al., 2007; Gurjar et al., 2010). In urban areas, the main sources of atmospheric aerosol particles are motor traffic, domestic heating, power generation, industrial processes (e.g. Allan et al., 2010; Aiken et al., 2009), while on a local scale additional sources such as cooking can come into play. In rural environments, particles are more significantly affected by local biogenic sources (e.g. Sjostedt et al., 2010; Slowik et al., 2010) but also long-range transport of polluted air masses (e.g. Dall'Osto et al., 2010; Dunlea et al., 2009; Healy et al., 2010; Singh et al., 2009; Hildebrandt et al., 2010).

It is well established that particles chemical composition is strongly depending on the gas-to-particle equilibrium. This is particularly true for ammonium nitrate which is known to be a semi-volatile compound. Moreover, organic aerosol concentrations are also dependent on their gas-to-particle equilibrium. For example, Bao et al. (2009) demonstrated

Published by Copernicus Publications on behalf of the European Geosciences Union. 
that the gas-to-particle equilibrium of low-molecular-weight dicarboxylic acids is not only dependent on the gas and particulate concentrations but it can also be linked to the temperature and relative humidity. Consequently, heterogeneous transfer and reaction processes have to be considered and might represent a source of secondary organic aerosols (SOA) as previously reported for chamber experiment (Volkamer et al., 2009). The organic compounds within the particles are mainly made of primary organic aerosol (POA) and semi-volatile compounds for freshly generated SOA and become less volatile through oxidative so-called "aging" processes (Jimenez et al., 2009; Ng et al., 2010). Consequently, a change in the gas-to-particle partitioning may be expected with increasing air mass age. Morgan et al. (2010) observed an important increase in nitrate and organics concentrations with altitude during airborne measurements over Europe which was correlated to variations in temperature and relative humidity. This underlines the fact that particle mass concentration is linked to both semivolatile precursor's concentrations and meteorological conditions. Moreover, the ammonium nitrate formation is not solely dependent on its gas-to-particle equilibrium; it is also directly depending on the available ammonia which competes with $\mathrm{HNO}_{3}$ and $\mathrm{H}_{2} \mathrm{SO}_{4}$ to lead to the formation of ammonium nitrate and ammonium sulfate respectively. In case of very low ammonia concentration, ammonia will preferentially react with $\mathrm{H}_{2} \mathrm{SO}_{4}$ and ammonium nitrate formation will be directly limited by ammonia. On the other hand, in case of very high concentration, formation of ammonium nitrate will be limited by the available nitric acid. Finally, in intermediate cases, reactivity of ammonia will be linked to the concentration of both $\mathrm{HNO}_{3}$ and $\mathrm{H}_{2} \mathrm{SO}_{4}$. Thus, as a consequence of the decrease in sulfur dioxide emissions observed over the last decades, a resulting increase in available ammonia would lead to an enhancement of ammonium nitrate concentration in the particles (Pye et al., 2009; Bauer et al., 2007). Such processes should become more important in agricultural areas where ammonia sources are more abundant by the use of soil fertilizers.

The presence of semi-volatile compounds in the particle phase also has a direct influence on the aerosol light scattering and radiative forcing (e.g. Morgan et al., 2010; Li et al., 2009); this might greatly affect the climate by increasing the total particle mass due to the condensation of semi-volatile compounds (Bauer et al., 2007). Regarding the legal regulation of the European Union for the $\mathrm{PM}_{10}$ mass concentration (European Directive 2008/50/EG), the question whether nitrate and semi-volatile organics are present in the particle phase or in the gas phase can be critical with respect to excess of the daily average legal limit value of $50 \mathrm{\mu g} \mathrm{m}^{-3}$ (Putaud et al., 2004).

The aim of this work is to perform a highly time-resolved aerosol particle study to describe the diurnal variations of organics and nitrate over a year and the influence of the meteorological conditions as well as the regional photo-chemistry.
For this an Aerodyne Aerosol Mass Spectrometer (AMS) was deployed during three intensive measurement campaigns in Melpitz together with a variety of other offline instrumentation. The measurements were integrated in the intensive measurement periods of the EU-Project EUCAARI (European Integrated Project on Aerosol Cloud Climate Air Quality Interactions, Kulmala et al., 2009), the programme EMEP (Co-operative programme for monitoring and evaluation of the long-range transmissions of air pollutants in Europe) and the UBA (Umweltbundesamt, the German federal environment agency) providing for the first time, at Melpitz, high time resolved aerosol chemical composition. These measurements covered different seasons: summer (May-June 2008), autumn (September-November 2008) and winter (FebruaryMarch 2009).

\section{Experimental}

\subsection{The research station Melpitz (Germany)}

All measurements were made at the IfT research station Melpitz $\left(12.93^{\circ} \mathrm{E}, 51.54^{\circ} \mathrm{N}\right), 50 \mathrm{~km}$ east of Leipzig, Germany. The station has been used since 1992 to examine the effect of atmospheric long range transport on local air quality. Since 2004, the station is part of the EMEP-level 3 network under the reference DE44. The site itself is mainly surrounded by agricultural pastures and forests. The atmospheric aerosol observed at Melpitz can be regarded as representative of Central European background conditions, as confirmed by multiple site comparisons within EUSAAR (European Supersites for Atmospheric Aerosol Research) and the German Ultrafine Aerosol Network (GUAN, Birmili et al., 2009 and Asmi et al., 2011). For a basic overview of the physical and chemical aerosol characterization methods, see e.g. Birmili et al. (2008), Spindler et al. (2010) and Spindler et al. (2004). Atmospheric aerosols observed at Melpitz range between two extremes: Atlantic (westerly) air masses with low particulate mass concentrations and continental (easterly) air masses with high particle mass concentrations (Birmili et al., 2001; Spindler et al., 2010). Differences between these air mass extremes are also manifested in their particulate chemical composition. The measurements were conducted during three field experiments, which covered different parts of the seasonal cycle. Table 1 provides an overview of these three campaigns.

Aerosol measurements were performed using both on-line and off-line instruments. All on-line instruments were set up in the same container laboratory and utilized the same air inlet. This inlet line consisted of a $\mathrm{PM}_{10}$ Anderson impactor located approximately $6 \mathrm{~m}$ above ground level. It was followed directly by an automatic aerosol diffusion dryer that maintained the relative humidity $(\mathrm{RH})$ in the sampling line below $30 \%$ all the time (Tuch et al., 2009). After entering the container laboratory, the sampling flow was divided among 
the various on-line instruments. The off-line measurements are based on filter samples that are described in Sect. 2.3.

\subsection{AMS measurements}

An Aerodyne High Resolution Time-of-Flight Aerosol Mass Spectrometer (HR-ToF-AMS, here simply referred to as AMS, DeCarlo et al., 2006) was typically operated at 5 min time resolution. Due to the $600^{\circ} \mathrm{C}$ surface temperature of the vaporizer, the AMS can only measure the non-refractory (NR) part of the particles. Soot, crustal material and sea-salt cannot be detected. Therefore, based on the aerodynamic lenses transmission efficiency and the detected compounds, AMS results are commonly considered to correspond to the

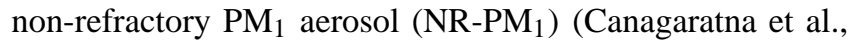
2007).

The calculation of the particles mass concentration from AMS data requires knowledge of the collection efficiency (CE) of the instrument. The CE value is known to depend on several parameters such as the nitrate content, particle acidity and relative humidity $(\mathrm{RH})$ in the sampling line (Huffman et al., 2005; Matthew et al., 2008). It is considered that in most cases, a CE of 0.5 represents a good assumption (e.g. Canagaratna et al., 2007). The contribution of relative humidity $(\mathrm{RH})$ to the $\mathrm{CE}$ was removed using a dried aerosol with $\mathrm{RH}<30 \%$ as previously mentioned. The CE was estimated by comparing the daily mean AMS sulfate concentrations against the daily $\mathrm{PM}_{1}$ filter concentrations (see Fig. SI 1 in Supplement). This evaluation yielded a CE of 0.38 and 0.5 for the autumn and winter campaigns, respectively. As no $\mathrm{PM}_{1}$ filter samples were performed during the summer campaign, a CE value of 0.5 was assumed, in line with the dried inlet, neutralized particles (see below) and the low nitrate content, during this measurement period.

High resolution analysis of the V-mode mass spectra was performed using the PIKA v1.08 software tools, downloaded from the ToF-AMS-Ressources webpage (http://cires.colorado.edu/jimenez-group/ ToFAMSResources/ToFSoftware/index.html). Applying the method developed by Aiken et al. (2007) and Aiken et al. (2008), the obtained high resolution organic mass spectra were used to determine the elemental composition and the $O M / O C, O / C$ and $H / C$ ratios.

\subsection{Filter samples}

Parallel to the AMS, $\mathrm{PM}_{1}$ particles were sampled using a Digitel DHA-80 high volume sampler (Digitel Elektronic AG, Hegnau, Switzerland). Sampling was performed every day during $24 \mathrm{~h}$ from midnight to midnight. Each $\mathrm{PM}_{1}$ sample was collected on pre-backed quartz fiber filters $(24 \mathrm{~h}$ at $105^{\circ} \mathrm{C}$ ) (Munktell Filter AB, Falun, Sweden). After sampling, the filters were conditioned for $48 \mathrm{~h}$ at $20 \pm 2{ }^{\circ} \mathrm{C}$ and $50 \%$ RH before being weighed by a microbalance MettlerToledo (AT 261). According to the analytical method of
Brüggemann and Rolle (1998), the filters were then analyzed using Ion Chromatography (Metrohm System 690, Switzerland) for the main water soluble ions $\left(\mathrm{Cl}^{-}, \mathrm{SO}_{4}^{2-}, \mathrm{NO}_{3}^{-}\right.$, $\mathrm{NH}_{4}^{+}, \mathrm{Na}^{+}, \mathrm{K}^{+}, \mathrm{Ca}^{2+}$ and $\mathrm{Mg}^{2+}$ ). Because filter samples were performed daily, an artefact due to the evaporation of the most volatile compounds (e.g. ammonium nitrate) during warm period cannot be completely excluded (Eatough et al., 1988; Keck and Wittmaack, 2005; Schaap et al., 2004).

\subsection{Other measurements}

The soot mass concentration was measured by a Multi-Angle Absorption Photometer (MAAP, Model 5012, Thermoscientific, Petzold and Schonlinner, 2004). To use MAAP data in conjunction with the AMS, which has an upper size cut-off around $1 \mu \mathrm{m}$, soot concentration for $\mathrm{PM}_{1}$ are required. Temporary but concurrent measurements using two MAAPs in parallel, one connected to the $\mathrm{PM}_{10}$ inlet, and a second one to a $\mathrm{PM}_{1}$ inlet demonstrated that the soot concentration in $\mathrm{PM}_{1}$ is around $90 \%$ of that in $\mathrm{PM}_{10}$, with this ratio being only weakly time-dependent. For our study here, we consequently estimated soot in $\mathrm{PM}_{1}$ by multiplying the soot concentration on $\mathrm{PM}_{10}$ by a constant factor of 0.90 . By combining the MAAP measurements and the AMS NR-PM chemical composition, a relatively comprehensive picture of chemical particle composition is provided. The particle size distribution was measured by a Twin Differential Mobility Particle Sizer (TDMPS, Birmili et al., 1999) in the range 3$800 \mathrm{~nm}$.

Standard meteorological parameters (temperature, RH, atmospheric pressure, solar radiation, precipitation, wind direction and wind velocity) were also continuously measured. During the summer campaign, gas phase measurements of $\mathrm{SO}_{2}, \mathrm{NO}_{\mathrm{x}}$ and $\mathrm{O}_{3}$ were complemented by measurements of sulfuric acid and ammonia concentrations, $\mathrm{OH}$ radical concentration and photolysis rates of $\mathrm{NO}_{2}$ and $\mathrm{O}\left({ }^{1} \mathrm{D}\right)$. Gaseous sulfuric acid and OH-radicals were measured by CIMS as previously described by Berresheim et al. (2000); Rohrer and Berresheim (2006) and Schlosser et al., 2009). The instrument was set up in a container located closed to the container laboratory previously described and sampled air from a height of $3 \mathrm{~m}$ above ground, $0.5 \mathrm{~m}$ above the container. From a continuous inlet air flow, a sample gas flow is split off in which $\mathrm{OH}$ is chemically titrated by addition of ${ }^{34} \mathrm{SO}_{2}$ to yield $\mathrm{H}_{2}^{34} \mathrm{SO}_{4} \cdot \mathrm{H}_{2}^{34} \mathrm{SO}_{4}$ is then selectively ionized by $\mathrm{NO}_{3}^{-}$ions at atmospheric pressure, and the resulting ions are transferred into a vacuum chamber through a counter flow of pure nitrogen gas by electrical fields. Here, ion-molecule clusters are broken up and the $\mathrm{H}^{34} \mathrm{SO}_{4}^{-}$ions are analyzed by mass spectrometry.

The $\mathrm{OH}$ concentration is obtained after correction for background $\mathrm{H}_{2} \mathrm{SO}_{4}$ and inlet chemistry, the latter taken into consideration the recycling of $\mathrm{OH}$ from $\mathrm{NO}+\mathrm{HO}_{2}$, and $\mathrm{OH}$-losses by $\mathrm{CO}, \mathrm{NMHC}$, and $\mathrm{NO}_{2}$. As clean rural to moderately polluted conditions were encountered in 
Table 1. Summary of the meteorological conditions for the three measurement periods.

\begin{tabular}{|c|c|c|c|}
\hline & Summer & Autumn & Winter \\
\hline Measurement period & $\begin{array}{l}23 \text { May- } \\
9 \text { Jun } 2008\end{array}$ & $\begin{array}{l}16 \text { Sep- } \\
3 \text { Nov } 2008\end{array}$ & $\begin{array}{l}24 \text { Feb- } \\
27 \text { Mar } 2009\end{array}$ \\
\hline $\begin{array}{l}\text { Temperature }\left({ }^{\circ} \mathrm{C}\right) \text { mean } \\
\text { (min.-max.) }\end{array}$ & $\begin{array}{l}19.5 \\
(5.2-31.7)\end{array}$ & $\begin{array}{l}10 \\
(-2.0-22.5)\end{array}$ & $\begin{array}{l}5.3 \\
(-3.3-14.2)\end{array}$ \\
\hline Atmospheric pressure $(\mathrm{hPa})$ & $1007.7 \pm 2.4$ & $1010.4 \pm 9.6$ & $1004.3 \pm 11.6$ \\
\hline $\begin{array}{l}\text { Relative Humidity (\%) mean } \\
\text { (min.-max.) }\end{array}$ & $\begin{array}{l}69.7 \\
(29.8-100)\end{array}$ & $\begin{array}{l}88.6 \\
(44.4-100)\end{array}$ & $\begin{array}{l}87.1 \\
(38.7-100)\end{array}$ \\
\hline Wind speed $\left(\mathrm{m} \mathrm{s}^{-1}\right)$ & $2.2 \pm 1.4$ & $2.2 \pm 1.7$ & $3.2 \pm 1.7$ \\
\hline Cumulative precipitation (mm) & 11.1 & 66.2 & 35.5 \\
\hline $\begin{array}{l}\text { Ozone }\left(\mu \mathrm{g} \mathrm{m}^{-3}\right) \\
\text { mean (min. }- \text { max. })\end{array}$ & $\begin{array}{l}85 \\
(5.1-164)\end{array}$ & $\begin{array}{l}39.8 \\
(4.9-108.4)\end{array}$ & $\begin{array}{l}60.5 \\
(6.1-103.2)\end{array}$ \\
\hline $\begin{array}{l}\text { Solar radiation }\left(\mathrm{W} \mathrm{m}^{-2}\right) \text { mean } \\
\text { (min.-max.) }\end{array}$ & $\begin{array}{l}264.1 \\
(0-914)\end{array}$ & $\begin{array}{l}81.4 \\
(0-688)\end{array}$ & $\begin{array}{l}76.8 \\
(0-687)\end{array}$ \\
\hline
\end{tabular}

Melpitz, the correction factors to compensate for chemically induced changes of $\mathrm{OH}$ in the inlet were typically $10 \%$ with a variability of $\pm 6 \%$. The system has a detection limit of $2 \times 10^{5}$ molecules $\mathrm{cm}^{-3}$ and an estimated uncertainty of $30 \%$.

The photolysis frequencies of $\mathrm{NO}_{2}$ and ozone to yield $\mathrm{J}\left(\mathrm{O}^{1} \mathrm{D}\right)$ were measured by sets of up- and downward looking actinic filter radiometers (MetCon), thus providing $4 \pi \mathrm{sr}$ photolysis rates. They were characterized and calibrated versus a reference spectral radiometer at FZ-Jülich (Bohn et al., 2008).

For the tropospheric ammonia measurements, an automatic photo-acoustic monitor TGA 310 (Omnisens, Switzerland) was used. The performance of this device was checked using NIST $\mathrm{NH}_{3}$ standard (type 40F3).

\section{Weather conditions overview}

The measurements presented here cover most of the seasonal weather conditions that are typical for Melpitz (Table 1). The first campaign, performed in summertime (from end-May to mid-June 2008), was representative for the summer conditions. It was characterized by a stable high pressure system, sunny days and almost without precipitation. Ozone concentration presented a clear diurnal profile with higher concentration during the day and lower concentration during the night. A large variation in temperature was observed between day and night times with amplitudes close to $20^{\circ} \mathrm{C}$. Similar diurnal changes were observed for the relative humidity. Most of the time, the wind-velocity was low and came from the eastern sector.
The second measurement period was performed in autumn (from mid-September to the beginning of November). This period covered the transition from summer to winter time. The temperature slowly decreased from a mean value of about $10.4^{\circ} \mathrm{C}$ at the beginning to a mean value of about $6.6^{\circ} \mathrm{C}$ at the end. Similarly, solar radiation also decreased from a maximum slightly below $700 \mathrm{~W} \mathrm{~m}^{-2}$ during the first week to $400 \mathrm{~W} \mathrm{~m}^{-2}$ during clear sky days and only $100 \mathrm{~W} \mathrm{~m}^{-2}$ during cloudy days at the end of the campaign. In parallel, RH increased and reached values close to saturation during the last week. Atmospheric pressure was less stable and alternate periods of low and higher pressure were observed. The ozone concentration was half of that during the summer campaign. On some days, ozone presented however a similar diurnal variation as in the summer campaign, especially during the first part of the campaign when photochemistry activities were still high and during most of the time we observed a relatively stable ozone concentration rather corresponding to a limited local production. Additionally, many precipitation events were observed during the whole campaign. According to the air mass influence discrimination made by Spindler et al. (2010), the sampling station was mainly influenced by eastern air masses (until beginning of October) and by western air masses (from October on).

The last campaign performed in wintertime (from midFebruary to mid-March 2009) was characterized by low temperatures, very low solar radiation and high RH close to saturation during the first half of the measurement period. The mean ozone concentration was higher than observed during the autumn with a marginal diurnal profile. Due to the low solar radiation, we conclude of a limited ozone formation. The winter period was also characterized by a slightly higher wind velocity, mainly coming from western directions. 
Table 2. Summary of the particle mass composition for the three measurement periods. The reported mass concentrations correspond to the mean value and the errors to the standard deviation calculated over each entire measurement period.

\begin{tabular}{|c|c|c|c|c|c|c|}
\hline & \multicolumn{3}{|c|}{ Mass concentration $\left(\mu \mathrm{g} \mathrm{m}^{-3}\right)$} & \multicolumn{3}{|c|}{ Mass fraction $(\%)$} \\
\hline & Summer & Autumn & Winter & Summer & Autumn & Winter \\
\hline Organics & $6.89 \pm 3.02$ & $3.87 \pm 2.62$ & $2.08 \pm 1.6$ & $59.0 \pm 9.1$ & $36.6 \pm 10.9$ & $22.6 \pm 9.8$ \\
\hline Nitrate & $0.66 \pm 0.57$ & $2.97 \pm 2.92$ & $3.62 \pm 3.27$ & $5.4 \pm 3.3$ & $23.2 \pm 11.9$ & $34.4 \pm 12.5$ \\
\hline Sulfate & $2.44 \pm 1.17$ & $1.67 \pm 1.01$ & $1.46 \pm 1.00$ & $21.5 \pm 6.9$ & $17.5 \pm 6.8$ & $17.6 \pm 8.3$ \\
\hline Ammonium & $0.94 \pm 0.45$ & $1.37 \pm 1.01$ & $1.69 \pm 1.21$ & $8.2 \pm 2.3$ & $12.3 \pm 2.9$ & $17.2 \pm 3.4$ \\
\hline Chloride & $0.02 \pm 0.01$ & $0.09 \pm 0.14$ & $0.13 \pm 0.11$ & $0.2 \pm 0.1$ & $0.7 \pm 0.7$ & $1.6 \pm 1.1$ \\
\hline Soot & $0.62 \pm 0.26$ & $0.99 \pm 0.73$ & $0.59 \pm 0.48$ & $5.6 \pm 1.9$ & $9.6 \pm 3.8$ & $6.5 \pm 3.3$ \\
\hline Total & $11.58 \pm 4.45$ & $11.03 \pm 7.2$ & $9.59 \pm 6.5$ & & & \\
\hline
\end{tabular}

Table 3. Comparison of inorganic composition of the daily $\mathrm{PM}_{1}$ and $\mathrm{PM}_{2.5}$ high volume sampler filters for autumn and winter (mean $\pm 1 \sigma$ standard deviation in $\mu \mathrm{g} \mathrm{m}^{-3}$ ).

\begin{tabular}{|c|c|c|c|c|}
\hline & \multicolumn{2}{|c|}{ Autumn } & \multicolumn{2}{|c|}{ Winter } \\
\hline & $\mathrm{PM}_{1}$ & $\mathrm{PM}_{2.5}$ & $\mathrm{PM}_{1}$ & $\mathrm{PM}_{2.5}$ \\
\hline Nitrate & $1.67 \pm 1.38$ & $3.31 \pm 2.49$ & $3.29 \pm 1.72$ & $4.73 \pm 2.50$ \\
\hline Sulfate & $1.53 \pm 0.55$ & $1.93 \pm 0.82$ & $1.50 \pm 0.70$ & $2.18 \pm 1.51$ \\
\hline Chloride & $0.05 \pm 0.04$ & $0.09 \pm 0.07$ & $0.09 \pm 0.06$ & $0.19 \pm 0.15$ \\
\hline Ammonium & $1.10 \pm 0.61$ & $1.59 \pm 0.81$ & $1.47 \pm 0.79$ & $2.17 \pm 1.36$ \\
\hline Sodium & $0.02 \pm 0.02$ & $0.04 \pm 0.07$ & $0.03 \pm 0.04$ & $0.14 \pm 0.16$ \\
\hline Calcium & $0.05 \pm 0.04$ & $0.06 \pm 0.02$ & $0.03 \pm 0.02$ & $0.03 \pm 0.03$ \\
\hline Potassium & $0.09 \pm 0.04$ & $0.11 \pm 0.05$ & $0.10 \pm 0.06$ & $0.12 \pm 0.07$ \\
\hline Magnesium & $0.01 \pm 0.004$ & $0.010 \pm 0.01$ & $0.005 \pm 0.003$ & $0.02 \pm 0.02$ \\
\hline
\end{tabular}

\section{Results}

\subsection{Seasonal changes of particle chemical composition}

The mean particle mass concentration (NR-PM 1 from AMS plus soot from MAAP) for the three measurement periods was relatively constant, ranging from $9.65 \mu \mathrm{g} \mathrm{m}^{-3}$ to $11.63 \mathrm{\mu g} \mathrm{m}^{-3}$ (details values can be found in Table 2). This is in agreement with the mean $\mathrm{PM}_{1}$ filter samples mass concentration measured simultaneously during the autumn $\left(11.91 \pm 4.67 \mu \mathrm{g} \mathrm{m}^{-3}\right)$ and winter $\left(11.39 \pm 5.57 \mu \mathrm{g} \mathrm{m}^{-3}\right)$ campaigns as well as the annual mean concentration of $12 \mu \mathrm{g} \mathrm{m}^{-3}$ reported by Spindler et al. (2010) for the period from 2004 to 2006 . The summer period was characterized by a large fraction of organic matter (OM) and sulfate. Throughout the year, the mass fraction of OM decreased and reached a minimum mass fraction in winter time. The mass fraction of sulfate to total $\mathrm{PM}_{1}$ appeared to be relatively stable during autumn and winter (around 17\%), while the mass fraction of nitrate strongly increased from a minimum value in summer and reached a maximum in winter. In a lower proportion, an increase of the mass fraction of ammonium and chloride was also observed from summer $(8.2 \%$ and $0.2 \%$, respectively) to winter ( $17.2 \%$ and $1.6 \%$, respectively). The observed seasonal changes are in good agreement with long- term measurements of particle chemical composition made at Melpitz using high volume $\mathrm{PM}_{1}$ Digitel filter samples by Spindler et al. (2010).

The neutralization state of the particles for each season was estimated using the same approach as described by Sun et al. (2010); Zhang et al. (2005a, 2007b) and based on the following equation:

$\mathrm{NH}_{4 \text { pred }}^{+}=18 \times\left(2 \times\left(\mathrm{SO}_{4}^{2-}\right) / 96+\left(\mathrm{NO}_{3}^{-}\right) / 62+\left(\mathrm{Cl}^{-}\right) / 35.5\right)(1)$

where $\mathrm{SO}_{4}^{2-}, \mathrm{NO}_{3}^{-}$and $\mathrm{Cl}^{-}$represent the mass concentrations (in $\mu \mathrm{g} \mathrm{m}^{-3}$ ) of the species divided by their molecular weight. The number 18 is the ammonium molecular weight. It is important to note that this equation by default builds on a full neutralization of the anions by ammonium and consequently that the inorganic species are present in the form of ammonium nitrate, ammonium sulfate and ammonium chloride. Moreover, Eq. (1) considers the contribution of metal ions, organic acids and bases to be negligible (Zhang et al., 2007b). Results of $\mathrm{PM}_{1}$ filter samples demonstrated (for autumn and winter campaigns, Table 3 ) that the contribution of $\mathrm{Na}^{+}, \mathrm{Ca}^{2+}, \mathrm{K}^{+}$and $\mathrm{Mg}^{2+}$ was in fact negligible due to their low concentrations compared to $\mathrm{NH}_{4}^{+}, \mathrm{SO}_{4}^{2-}$ and $\mathrm{NO}_{3}^{-}$. Depending on the ratio between predicted and measured $\mathrm{NH}_{4}$ 

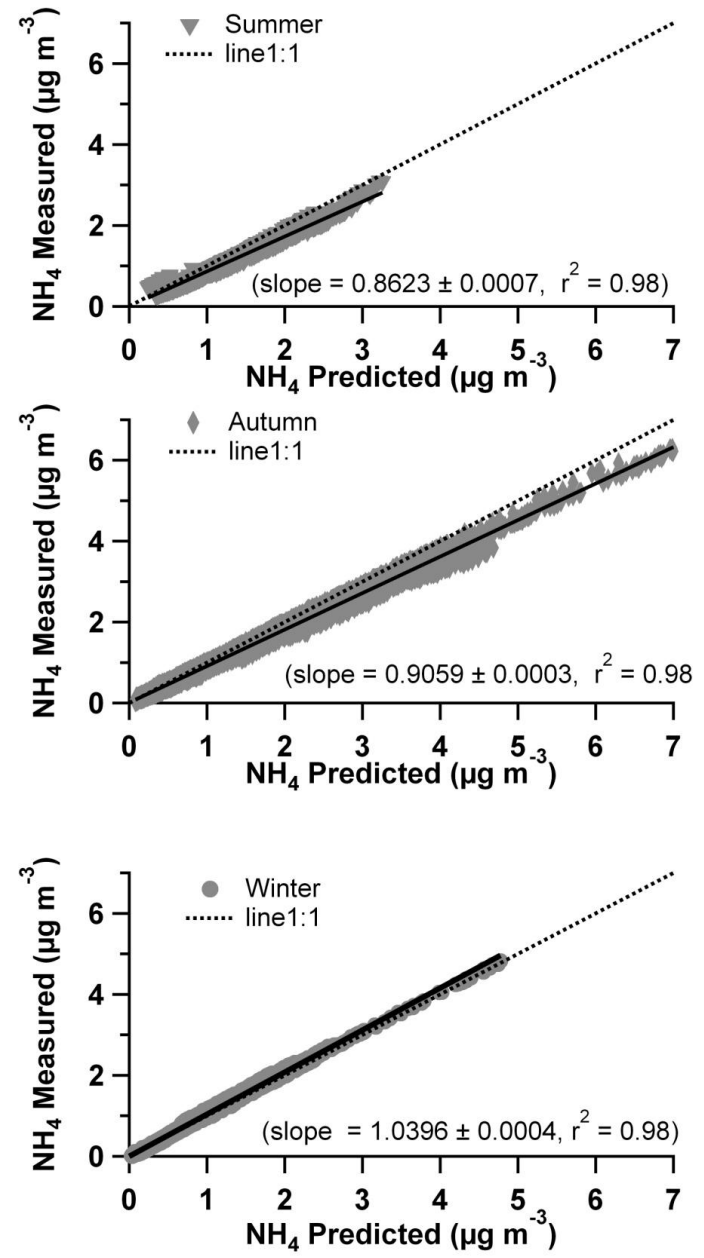

Fig. 1. Comparison of the measured ammonium with the predicted ammonium concentration assuming a fully neutralization by nitrate, sulfate and chloride for the three different campaigns.

concentrations, particles are considered to be fully neutralized according to Eq. (1) if the estimated ammonium concentration predicts is similar to the measured ammonium concentration and to be more acidic if the estimated ammonium concentration is significantly lower than predicted ammonium (slope below 0.75 according to Zhang et al., 2007b).

The results presented in Fig. 1 show that the particles can be considered to be fully neutralized during the different seasons allowing for to the instrumental uncertainties and a minor contribution of the organic nitrate and organic sulfate to the nitrate and sulfate signals (Farmer et al., 2010). The lower slope value of the summer cannot completely exclude the presence of a limited amount of ammonium bisulfate once in a while, especially not during events of intensive new particle formation (see discussion in Sect. 4.3.2). This also indicates that there is enough ammonia in the gas phase to fully neutralize particle nitrate and sulfate. The origin of the ammonia in the gas phase can be partially explained by the location of the sampling station which is surrounding by agriculture fields and land. Evaporation of the $\mathrm{NH}_{3}$-based fertilizer present on the fields, especially during warm day time, can be expected.

Complementary to the long-term filter samples measurements; the AMS with its high time resolution gave the opportunity to investigate the diurnal variations of the particle's chemical composition. In the following, results on the seasonal changes of aerosol organic matter and nitrate are presented and discussed.

\subsection{Changes in organic aerosol}

\subsubsection{Comparison of the organic aerosol mass spectra}

The averaged high resolution organic mass spectrum (HRMS) of each campaign is presented in Fig. 2. According to their composition, the organic fragments were divided in different ion categories $\left(\mathrm{C}_{\mathrm{x}}^{+}, \mathrm{C}_{\mathrm{x}} \mathrm{H}_{\mathrm{y}}^{+}, \mathrm{C}_{\mathrm{x}} \mathrm{H}_{\mathrm{y}} \mathrm{O}^{+}\right.$and $\left.\mathrm{C}_{\mathrm{x}} \mathrm{H}_{\mathrm{y}} \mathrm{O}_{z}^{+}\right)$. The contribution of each category to the total organic signal as well as the corresponding elemental composition of $\mathrm{C}, \mathrm{H}$ and $\mathrm{O}$ atoms is also presented in Fig. 2. The contribution of $\mathrm{C}_{\mathrm{x}} \mathrm{H}_{\mathrm{y}}^{+}$was rather constant during the three campaigns and represented almost $50 \%$ of organic aerosol (OA). The oxygenated categories, $\mathrm{C}_{\mathrm{x}} \mathrm{H}_{\mathrm{y}} \mathrm{O}^{+}$and $\mathrm{C}_{\mathrm{x}} \mathrm{H}_{\mathrm{y}} \mathrm{O}_{\mathrm{z}}^{+}$, represented the remaining $50 \%$ of $\mathrm{OA}$ and a small change of the respective contribution of $\mathrm{C}_{\mathrm{x}} \mathrm{H}_{\mathrm{y}} \mathrm{O}^{+}$and $\mathrm{C}_{\mathrm{x}} \mathrm{H}_{\mathrm{y}} \mathrm{O}_{\mathrm{z}}^{+}$has been observed between summer and the two other seasons. However, the average elemental composition did not show a pronounced seasonal variation.

The structure of the HRMS for each season was very similar. The most important peak was $\mathrm{m} / \mathrm{z} 44$ which is characteristic of highly oxidized OA (e.g. Alfarra et al., 2004; Zhang et al., 2005a). The $\mathrm{CO}_{2}^{+}$fragment was the most important contributor to $\mathrm{m} / \mathrm{z}, 44$ and represented more than $95 \%$ of the total $\mathrm{m} / \mathrm{z} 44$ signal. The presence of $\mathrm{CO}_{2}^{+}$can be attributed to multifunctional organic acids (Takegawa et al., 2007).

The second most important peak was $m / z 43$. However, the contribution of $\mathrm{m} / \mathrm{z} 43$ to total HRMS decreased from summer to winter. The fragment $\mathrm{m} / \mathrm{z} 43$ was basically made of two fragments, $\mathrm{C}_{2} \mathrm{H}_{3} \mathrm{O}^{+}$and $\mathrm{C}_{3} \mathrm{H}_{7}^{+}$(Fig. SI 2). The fragment $\mathrm{C}_{2} \mathrm{H}_{3} \mathrm{O}^{+}$was the most important fragment of $\mathrm{m} / \mathrm{z}, 43$ during the three campaigns. However, the contribution of $\mathrm{C}_{2} \mathrm{H}_{3} \mathrm{O}^{+}$ was slightly higher in summer $(92 \%)$, than in autumn ( $84 \%)$ and winter $(80 \%)$ due to a slightly higher contribution of $\mathrm{C}_{3} \mathrm{H}_{7}^{+}$in these seasons.

The fragment $m / z 57$ which is commonly considered as a tracer for primary organic emissions of fossil fuel combustion (Zhang et al., 2005b; Canagaratna et al., 2004; Aiken et al., 2008) had a low contribution to total HRMS. The $m / z, 57$ was made of two fragments, $\mathrm{C}_{3} \mathrm{H}_{5} \mathrm{O}^{+}$and $\mathrm{C}_{4} \mathrm{H}_{9}^{+}$. The contribution of each fragment to the total $\mathrm{m} / \mathrm{z} 57$ signal changed during the three campaigns (Fig. SI 2). While in summer, $\mathrm{m} / \mathrm{z} 57$ was principally made of $\mathrm{C}_{3} \mathrm{H}_{5} \mathrm{O}^{+}(68 \%$ of total $\mathrm{m} / z 57$ signal), the contribution of $\mathrm{C}_{4} \mathrm{H}_{9}^{+}$increased in autumn 


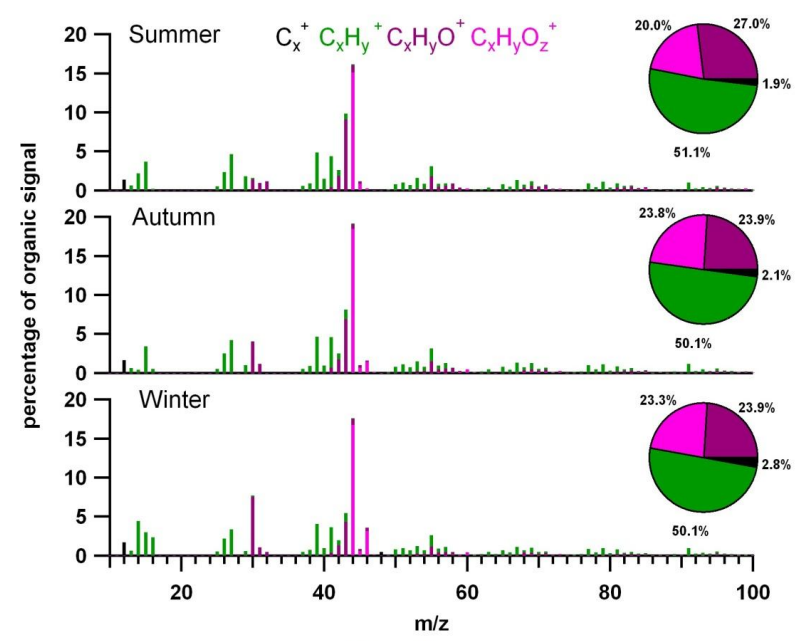

Another important organic fragment is the $\mathrm{m} / \mathrm{z} 55$ which like $m / z 57$ is often associated to primary organic emission (Alfarra et al., 2004; Canagaratna et al., 2004). The fragment $m / z 55$ was made of $\mathrm{C}_{3} \mathrm{H}_{3} \mathrm{O}^{+}$and $\mathrm{C}_{4} \mathrm{H}_{7}^{+}$. Similarly to $m / z 57, m / z 55$ was basically made of the oxygenated fragment, $\mathrm{C}_{3} \mathrm{H}_{3} \mathrm{O}^{+}$. However, a slight increase of the nonoxygenated fragment could again be observed in autumn and winter (Fig. SI 2). In addition, the diurnal variation of the different seasons was very similar to $m / z 57$.

The composition of the main organic fragments $(\mathrm{m} / \mathrm{z} 43$, 55 and 57) indicated that in Melpitz, organic aerosol was dominated by oxygenated organic aerosol, with a low contribution of primary organic aerosol during the different measurement campaigns. Because of a larger concentration of $\mathrm{C}_{4} \mathrm{H}_{9}^{+}$and a clear peak of $\mathrm{C}_{4} \mathrm{H}_{7}^{+}$and $\mathrm{C}_{4} \mathrm{H}_{9}^{+}$early in the morning during the autumn campaign, a small contribution of POA might be expected during this period.

Finally, the presence of biomass burning organic aerosol is generally linked to the $m / z, 60$ (Alfarra et al., 2007; Schneider et al., 2006). During the different seasons, $\mathrm{m} / \mathrm{z} 60$ had a small contribution to total OA (around $0.3 \%$ ). Such low contribution of $m / z 60$ to total OA was considered as representative for a background level value of SOA dominated ambient organic aerosol (Cubison et al., 2011). Based on the $\mathrm{m} / \mathrm{z} 60$ contribution, it is concluded that there is only a minor influence of biomass burning aerosol on total OA, even during winter. However, like for POA, a limited contribution of biomass burning seems to be suggested during the autumn campaign due to the small increase of $\mathrm{m} / \mathrm{z} 60$ contribution to OA.

\subsubsection{Changes on the organic oxidation states}

Fig. 2. Comparison of the average organic mass spectra for each season, color code stand for the main organic categories (top) and the main elements $(\mathrm{C}, \mathrm{H}$, and $\mathrm{O})$ (bottom). The pie charts represent the average mass fraction of the different ion categories and elemental composition of each mass spectrum.

$(53 \%)$ and winter $(57 \%)$. Comparing the diurnal profiles of these two fragments during the different campaigns, a small increase of $\mathrm{C}_{4} \mathrm{H}_{9}^{+}$early in the morning during summer and autumn can be observed (Fig. SI 2). This might indicate a possible increase of primary organic aerosol at this time. It has been shown for a rural station in Canada that the ratios of $\mathrm{C}_{3} \mathrm{H}_{5} \mathrm{O}^{+}$to $\mathrm{C}_{4} \mathrm{H}_{9}^{+}$increased with photochemical aging (Liggio et al., 2010). Therefore, these authors suggest that the $\mathrm{C}_{3} \mathrm{H}_{5} \mathrm{O}^{+}$might be associated with SOA and/or oxidized POA. Following this, the largest contribution of the $\mathrm{C}_{3} \mathrm{H}_{5} \mathrm{O}^{+}$ during summer might be attributed to a larger photochemistry aging $\mathrm{OA}$, while the high correlation between $\mathrm{C}_{3} \mathrm{H}_{5} \mathrm{O}^{+}$ and $\mathrm{C}_{4} \mathrm{H}_{9}^{+}$, observed during each campaign $\left(r^{2}=0.60,0.65\right.$ and 0.65 in summer, autumn and winter, respectively), might suggest a similar source for these two ions.

Several factors may influence the organic aerosol oxidation states like the thermodynamic properties of the organic compounds (e.g. volatility) related to the local temperature, aging processes of the organic aerosol and dynamics of the atmosphere. All these possible influences will be discussed in the following. Changes in organic oxidation levels were followed using three different approaches: (i) organic fragments $\mathrm{m} / \mathrm{z} 44\left(\mathrm{CO}_{2}^{+}\right)$and $\mathrm{m} / \mathrm{z} 43$ (mostly $\mathrm{C}_{2} \mathrm{H}_{3} \mathrm{O}^{+}$as described above), (ii) the $\mathrm{OM} / \mathrm{OC}, \mathrm{O} / \mathrm{C}$ and $\mathrm{H} / \mathrm{C}$ ratios calculated using the elemental analysis method developed by Aiken et al. (2007) and Aiken et al. (2008) and (iii) the carbon oxidation state (OSc), a newly method developed by Kroll et al. (2011). Their diurnal variations for each campaign are presented in Fig. 3. Generally, a more or less pronounced decrease of the organic fragments $(\mathrm{m} / \mathrm{z}, 44$ and $\mathrm{m} / \mathrm{z}, 43)$ was observed during day time compared to night time. Such diurnal variations can be attributed to both dynamics effects, correlated with the increase of the mixed layer height, and thermodynamic properties of the organic compounds (typically their volatility). For this reason, $\mathrm{m} / \mathrm{z}, 44$ and $\mathrm{m} / \mathrm{z}, 3$ were normalized to the total OM concentration according to the respective notation $f 44$ and $f 43$. Moreover, it is known 

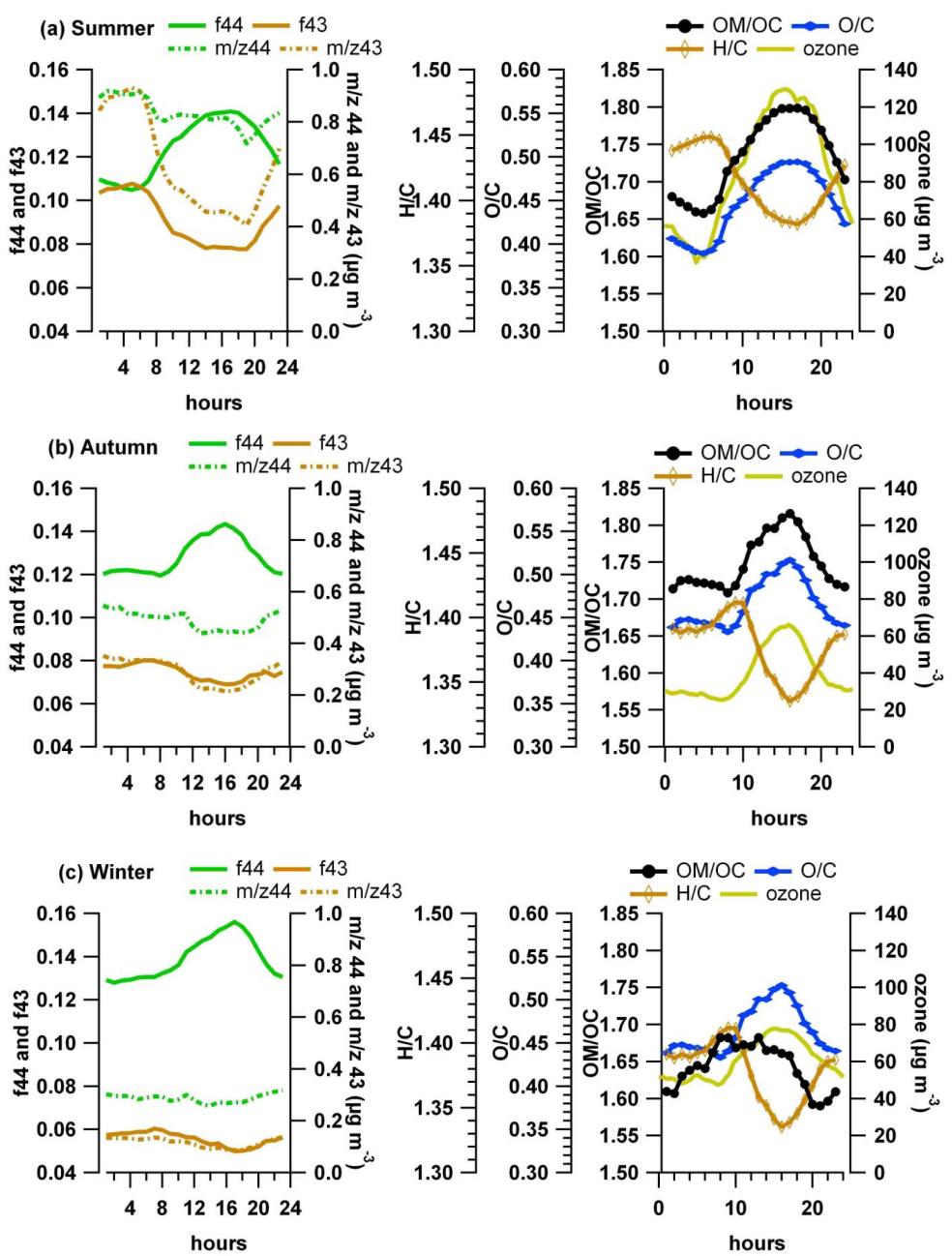

Fig. 3. Diurnal variations of the organic aerosol tracers $(\mathrm{m} / \mathrm{z}, 44, \mathrm{~m} / \mathrm{z}, 43, \mathrm{f} 44, \mathrm{f} 43), \mathrm{OM} / \mathrm{OC}, \mathrm{O} / \mathrm{C}$ and $\mathrm{H} / \mathrm{C}$ ratios and ozone concentration for (a) summer, (b) autumn and (c) winter.

that $f 44>f 43$ generally characterizes highly oxygenated and low volatile OA, while $f 44<f 43$ generally characterizes less oxygenated and semi-volatile OA (Ng et al., 2010). A comparison of the resulting diurnal profiles of $f 44$ and $f 43$ revealed a similar trend for all measurement periods with anti-correlated profiles. The seasonal variations of the diurnal patterns are discussed below.

Mean $O M / O C$ ratios of $1.73 \pm 0.06,1.74 \pm 0.09$ and $1.64 \pm 0.14$ were obtained for the summer, autumn and winter campaigns, respectively. These values are lower than the value of 2.1, which has been recommended for non-urban regimes by Turpin and Lim (2001). However, our values of $O M / O C$ ratios are still within the range of the values previously reported for similar sampling locations by Bae et al. (2006), Chan et al. (2010) and references therein. In addition, a small seasonal variation was observed, $O M / O C$ being higher in summer than in winter, which could be explained by a higher efficiency of particle photooxidation and SOA formation in summer than in winter. This is in agreement with conclusions drawn by Chan et al. (2010). As for $f 44$ and $f 43$, the diurnal profiles of the $O M / O C, O / C$ and $H / C$ ratios are represented in Fig. 3 (right panel). Typically, $O M / O C$ ratio showed the highest value during day time and a lower value during the night. A similar diurnal variation with a lower $O M / O C$ ratio during night compared to day time has also been reported by Yu et al. (2005a) at the rural station of Great Smoky Mountains National Park (Tennessee, USA).

The diurnal variations of $\mathrm{m} / \mathrm{z}, 44$ and $\mathrm{m} / \mathrm{z}, 3$ for the summer period show a strong decrease during day time, while $f 44, O M / O C$ and $O / C$ increase at the same time. These differences can be directly linked to the dynamics of the atmosphere, e.g. the increase of the mixed layer, which contributes to a dilution process by mixing the lower layer of the atmosphere with cleaner air from aloft. However, the 


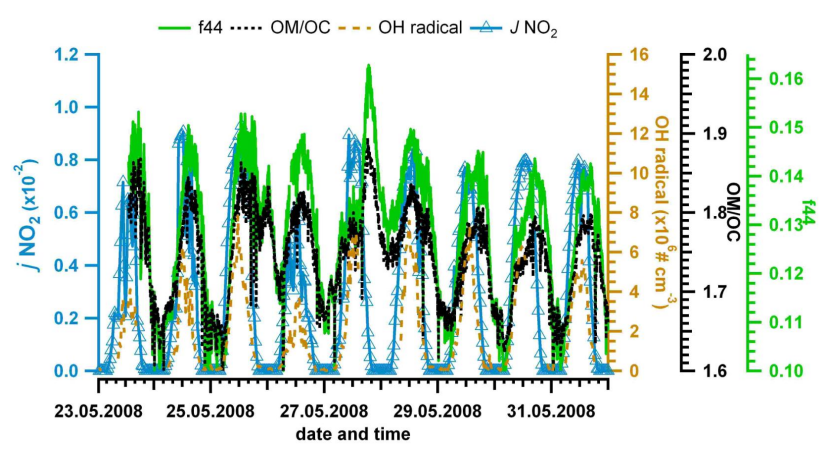

Fig. 4. Comparison of the $f 44$ and $O M / O C$ time series with the $\mathrm{OH}$ radical concentration and $\mathrm{NO}_{2}$ photolysis rate for the summer campaign.

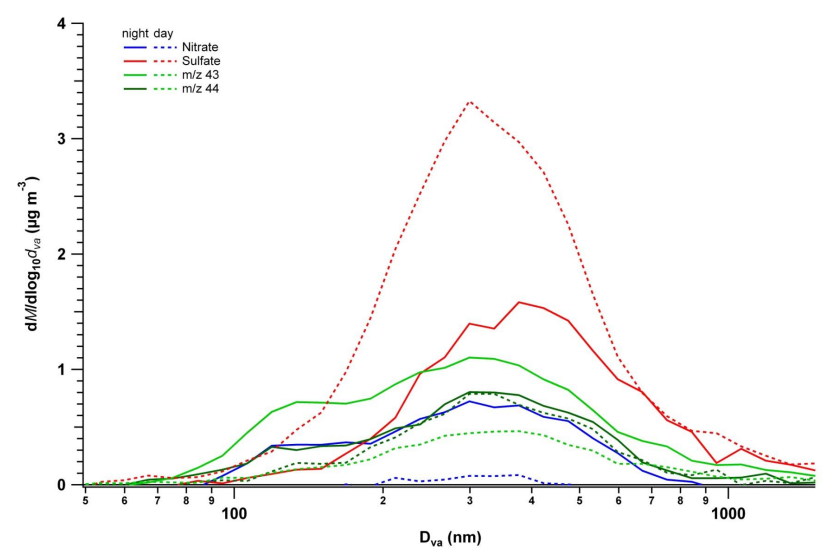

Fig. 5. An example of a typical summer night and day particle size distribution as measured on 7 June 2008. Night referred from midnight to 04:00 and day from noon to 18:00.

increase of $f 44, O / C$ and $O M / O C$ reveals an important change of the oxidation level of OA. In parallel to these changes in the OA oxidation state, an increase of $\mathrm{OH}$ radical concentration was measured during day time with a maximum around $8 \times 10^{6}$ molecules $\mathrm{cm}^{-3}$ in agreement with $\mathrm{OH}$ concentrations observed by Hock et al. (2008) and Holland et al. (2003) at different rural places in Germany during similar periods of the year. The time series of the $\mathrm{OH}$ concentration were compared to the time series of $f 44$ and $O M / O C$ (Fig. 4). With the exception of 27 May 2008, the increase of $\mathrm{OH}$ concentration is correlated to an increase of $f 44$ and $O M / O C$, which indicates that a change in OA oxidation state can be linked to photochemical aging. This is illustrated in Fig. 3, which presents similar profiles of organic tracers $(f 44, O / C, O M / O C)$ and ozone concentrations while $\mathrm{f} 43$ and $H / C$ profiles anti-correlate with ozone concentration (correlation plots are available in Fig. SI 3; $f 44$ vs. $\mathrm{O}_{3} r^{2}=0.96, f 43$ vs. $\mathrm{O}_{3} r^{2}=0.96$ and $O M / O C$ vs. $\mathrm{O}_{3}$ $r^{2}=0.98$ ) indicating that photochemical aging of particles during day time leads to the formation of more oxidized OA. This was also shown in previous studies (e.g. Hildebrandt et al., 2010 and Sjostedt et al., 2010). Furthermore, the condensation of low volatile compounds produced during VOCs ozonolysis on pre-existing particles cannot be excluded and should therefore be taken into consideration, additionally to the OA aging process. When $f 44$ increased, $f 43$ decreased which might be explained by the presence of more low-volatile compounds in the OA as well as by the oxidation of the OA, leading to conversion of $\mathrm{m} / \mathrm{z} 43$ to $\mathrm{m} / \mathrm{z} 44$ ( $\mathrm{Ng}$ et al., 2010). However, during the night, f43 strongly increased and consequently $f 44$ decreased, indicating the presence of more semi-volatile compounds. Due to the previously mentioned large difference of temperature between day and night time (up to $20^{\circ} \mathrm{C}$ ), evaporation of the more volatile organic fraction during day time and its condensation in the evening have to be taken into account. The semivolatile $\mathrm{OA}$ has a lower $O M / O C$ ratio than a low volatile OA (Aiken et al., 2008; Jimenez et al., 2009). This could then explain the observed diurnal variation of the $O M / O C$ ratio. A typical night and day size distribution of organic mass $m / z, 43$ and $m / z, 44$ during summer are presented in Fig. 5. The night size distribution corresponded to the averaged size distribution measured from midnight to 04:00; and the day size distribution corresponded to the average size distribution measured from noon to 18:00. Although the size distribution of $m / z 44$ and $m / z 43$ during the day presented a maximum around $300 \mathrm{~nm}$, the night size distribution exhibited a clear double mode, with a first maximum at $120 \mathrm{~nm}$ and a second one around $300 \mathrm{~nm}$, similar to the maxima observed during day. The night size distribution of sulfate, which is known to be a low volatile compound, did not show any double mode. The lower sulfate concentration observed during the night may be attributed to the absence of sulfate formation and a lower mixed layer height. At the same time, the particle size distribution measured by the TDMPS (Fig. SI. 4 ), presents a clear increase in both volume and surface size distributions at similar diameter than the reported increase of organic tracer and nitrate (see discussion above for this last compound) during the night compare to day time. Such differences in the particle size distribution during day and night is in accordance with the already suggested condensation of semi-volatile organic compounds on pre-existing particle during the night. This phenomenon is certainly emphasized by the large diurnal difference of temperature, as mentioned above. On the other hand, Bessagnet et al. (2010) demonstrated that deposition of semi-volatile organic compounds may be an important factor especially during nighttime. Therefore, such process should contribute to limit the observed nighttime condensation on pre-existing particles.

During the autumn campaign, the decrease of the total OA during day time was less pronounced, suggesting a lower contribution of the dynamics of the atmosphere to the total particle concentration. Regarding the oxidation state of the $\mathrm{OA}$, the changes of $\mathrm{f} 43$ during the day were less pronounced, 


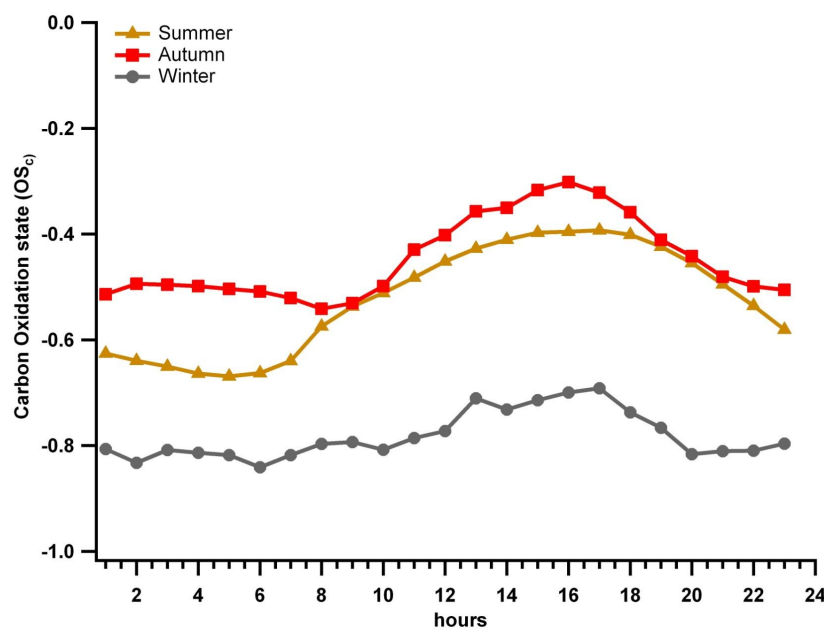

Fig. 6. Diurnal cycle of the carbon oxidation state for each season.

which might be explained by a lower aging process and/or a lower impact of the temperature variation between day and night times compared to summertime. However, as already observed during summertime, an increase of $f 44$ and $O M / O C$ ratio during day time was observed, which again - based on the similarity with the ozone pattern (Fig. SI-3; $O M / O C$ vs. $\mathrm{O}_{3}: r^{2}=0.96$ and $f 44$ vs. $\left.\mathrm{O}_{3}: r^{2} 0.96\right)-$ could be related to photooxidation processes.

During the winter campaign, contrary to the other seasons (summer and autumn) organic fragments $(\mathrm{m} / \mathrm{z}, 44$ and $\mathrm{m} / \mathrm{z}, 43$ ) did not show pronounced diurnal variations. A small peak was observed at night and a limited dip during day time. This might be explained by the limited impact of the dynamics of the atmosphere as well as by the thermodynamic properties of the OA, because of the lowest temperature at this period. As described in Sect. 3, ozone had only a small diurnal variation in winter and only $f 44$ seemed to be slightly correlated to the ozone variation (Fig. SI $3, f 44$ vs. $\mathrm{O}_{3}: r^{2}=0.94$ ) while $f 43$ still anticorrelated to ozone (Fig. SI $3, f 43$ vs. O3: $\left.r^{2}=0.75\right)$. It is known that during winter time, photolysis rates are lower, which limits consequently the ozone formation and photo-aging process. Therefore, these factors should only have a small impact on the diurnal variation of $O M / O C$. Moreover, due to low biogenic emissions during winter time, local sources of OA and SOA formation should also be limited. Thus, particles measured during winter time could - when compared with other seasons - mainly have been subject to long-range transport in agreement with long term measurements (Spindler et al., 2010).

Kroll et al. (2011) developed another approach to follow and compare changes of OA oxidation state. The authors determined the carbon oxidation state $(\mathrm{OSc})$ from the $\mathrm{O} / \mathrm{C}$ and $H / C$ ratios, as follows:

$\overline{\mathrm{OS}}_{c} \approx 2 O / C-H / C$
The OSc diurnal profiles for each campaign are shown in Fig. 6. The resulting OSc values are in the range of previously reported values for remote/biogenic aerosol ( -0.9 to $-0.2)$ and in the lower range of the reported values for aged OA ( -0.6 to +0.6$)$ (Kroll et al., 2011). Summer and autumn periods presented similar OSc diurnal profiles. In line with the discussion above, this corresponds to an increase of the oxidation state during day time and can be attributed to aging processes. The lowest values of OSc and the absence of well pronounce diurnal variations in winter confirm the presence of less processed OA and only a small amount of aging during day.

\subsection{Changes in particulate nitrate concentrations}

\subsubsection{Nitrate diurnal profiles}

As discussed previously (see Sect. 4.1), the nitrate concentrations vary strongly with different seasons. The highest concentrations of ammonium nitrate were observed during winter, which is in agreement with the long-term measurements made in Melpitz (Spindler et al., 2010). However, the high time resolution of the AMS provides an access to the diurnal variation of the nitrate concentration for the different seasons, as shown for the organics in the preceding section. The diurnal variation of the nitrate aerosol mass concentration is presented in Fig. 7. A relatively similar pattern can be observed in all three campaigns: a decrease of nitrate concentration during the day, reaching a minimum at the end of the afternoon followed by an increase during the night. As discussed in Sect. 4.1, the measured nitrate can principally be attributed to ammonium nitrate during the different campaigns. Nevertheless, it is not possible to exclude a limited contribution of the organic nitrate to our nitrate signal (Farmer et al., 2010).

The particulate ammonium nitrate is a semi-volatile compound in equilibrium with its gas phase precursors $\left(\mathrm{HNO}_{3}\right.$ and $\mathrm{NH}_{3}$ ). Therefore in the following discussion, we will only consider a simplified system only consisting of ammonium nitrate in equilibrium with its gas phase precursors $\left(\mathrm{NH}_{3}\right.$ and $\left.\mathrm{HNO}_{3}\right)$. The gas-to-particle phase partitioning of ammonium nitrate is well described in the literature and strongly depends on the gas phase precursors concentrations, temperature, relative humidity $(\mathrm{RH})$ and aerosol chemical composition (e.g. Seinfeld and Pandis, 2006; Mozurkewich, 1993; Ansari and Pandis, 2000; Nenes et al., 1998). In Fig. 7, the relationship between nitrate concentration, temperature and RH can clearly be observed. The nitrate concentrations were basically anticorrelated with temperature and correlated with RH. This is in agreement with results reported by $\mathrm{Ru}-$ pakheti et al. (2005) who also related the nitrate diurnal profile to temperature and $\mathrm{RH}$ variations.

The gas-to-particle equilibrium of ammonium nitrate can be described by the following reactions:

$\mathrm{NH}_{3}(\mathrm{~g})+\mathrm{HNO}_{3}(\mathrm{~g}) \rightleftharpoons \mathrm{NH}_{4} \mathrm{NO}_{3}(\mathrm{~s})$ 
$\mathrm{NH}_{3}(\mathrm{~g})+\mathrm{HNO}_{3}(\mathrm{~g}) \rightleftharpoons \mathrm{NH}_{4}^{+}(l)+\mathrm{NO}_{3}^{-}(l)$

Reaction (R1) corresponds to the gas-to-particle partitioning of dry ammonium nitrate particle. The dissociation equilibrium constant of ammonium nitrate into $\mathrm{HNO}_{3}$ and $\mathrm{NH}_{3}\left(K_{p}\right)$ was described by the following equation (Mozurkewich, 1993):

$\ln \left(K_{p}\right)=118.87+\frac{24080}{T}-6.025 \ln (T)$

For deliquescent particles, the influence of RH should be considered. Therefore, for $\mathrm{RH}<99.7 \%$, Reaction (R2) can be described by the following equation (Mozurkewich, 1993):

$K_{p}^{*}=\left(\mathrm{P} 1-\mathrm{P} 2\left(1-a_{\mathrm{w}}\right)+\mathrm{P} 3\left(1-a_{\mathrm{w}}\right)^{2} \times\left(1-a_{\mathrm{w}}\right)^{1.75} \times K_{p}(4)\right.$

with

$\ln (P 1)=-135.94+\frac{8763}{T}+19.12 \ln (T)$

$\ln (P 2)=-122.65+\frac{9962}{T}+16.22 \ln (T)$

$\ln (P 3)=-182.61+\frac{13875}{T}+24.46 \ln (T)$

and $a_{\mathrm{w}}=\mathrm{RH} / 100$ water activity approximation in the range 0 to 1 (Topping et al., 2005; Kreidenweis et al., 2008).

Moreover, in the ideal system considered here, when RH increases, the transition from solid phase equilibrium (R1) to aqueous phase (R2) directly depends on the ambient RH value compared to the Deliquescence Relative Humidity (DRH) of the particle. When RH decreases, the transition from R2 to R1 depends on the ambient RH value compared to the Efflorescence Relative Humidity (ERH). For example, at $298 \mathrm{~K}$, pure ammonium sulfate particles have a DRH of $80 \%$ and an ERH of $35 \%$ while pure ammonium nitrate particles have a DRH of $62 \%$ and no ERH is observed (Seinfeld and Pandis, 2006; Martin et al., 2003). For RH values lying between the values of DRH and ERH, particles are in a socalled metastable state; and in this condition, the prediction whether particles are in solid or liquid phase does not depend on the chemical composition of the particle only, but also on the RH history of the particles (Martin et al., 2003). Particles containing a significant fraction of ammonium nitrate have the tendency to remain liquid, even for quite low ambient RH (Shaw and Rood, 1990). Similarly, Martin et al. (2003) draw the conclusion that in Europe, due to their RH history, particles with chemical composition far from pure ammonium sulfate should remain liquid at $293 \mathrm{~K}$. Consequently, regarding the RH values and the diurnal variations of RH during the different seasons, most of the aerosol is considered to be in the aqueous phase. Therefore, R2 and equation Eq. (4) can be considered to describe the dissociation equilibrium of

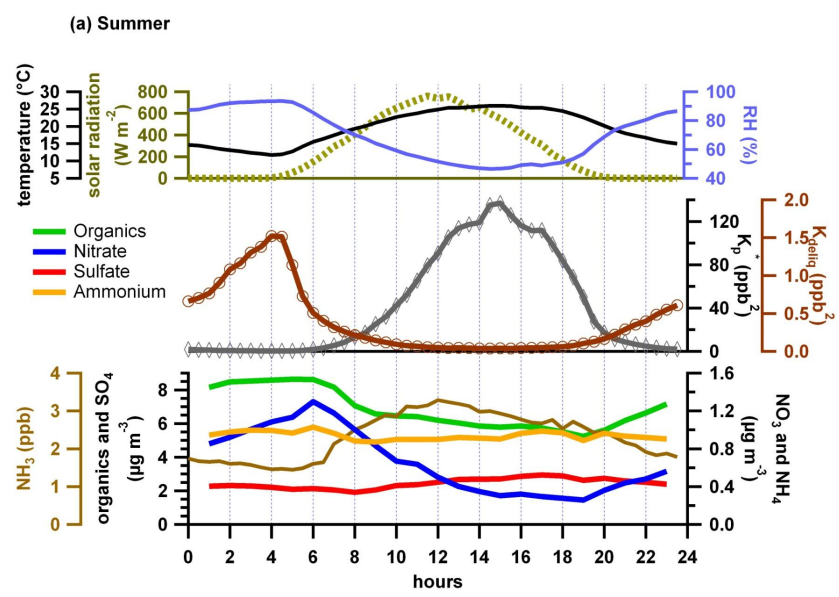

(b) Autumn

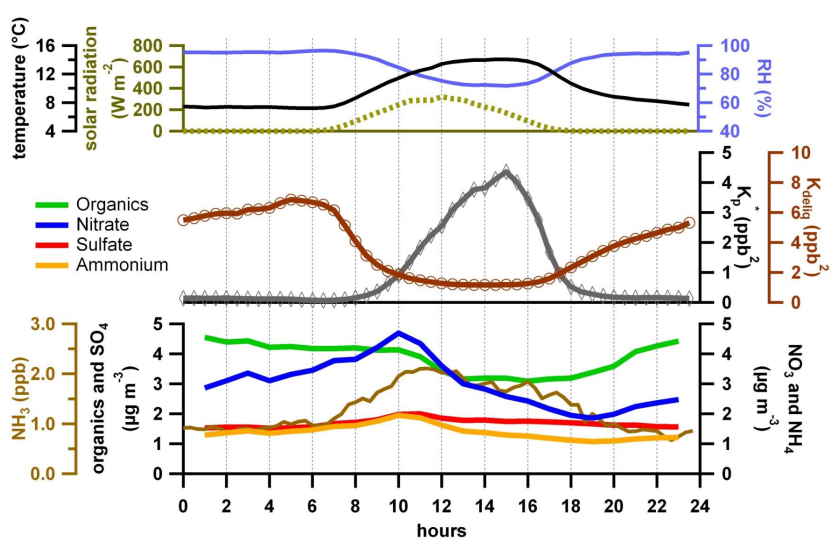

(c) Winter

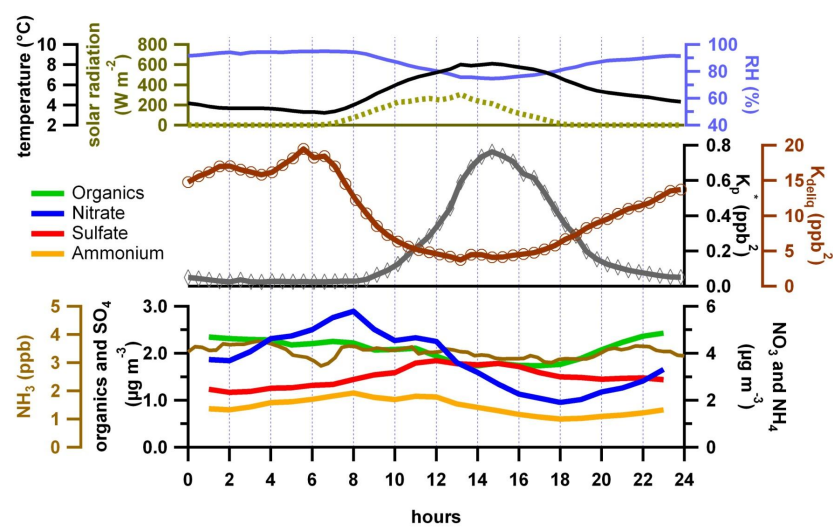

Fig. 7. Diurnal variations of the nitrate concentration and its thermodynamic constants for (a) summer, (b) autumn and (c) winter.

ammonium nitrate in an ideal system made of $\mathrm{NH}_{3}, \mathrm{HNO}_{3}$ and $\mathrm{H}_{2} \mathrm{O}$.

Still considering the ideal system, $K_{p}^{*}$ was calculated for each season (with $\mathrm{RH}<99.7 \%$ ) and its time series and diurnal variations are presented in Figs. 7 and 8. Even if the absolute values of $K_{p}^{*}$ correspond to equilibrium of pure ammonium nitrate, it is noticeable that the nitrate concentrations 


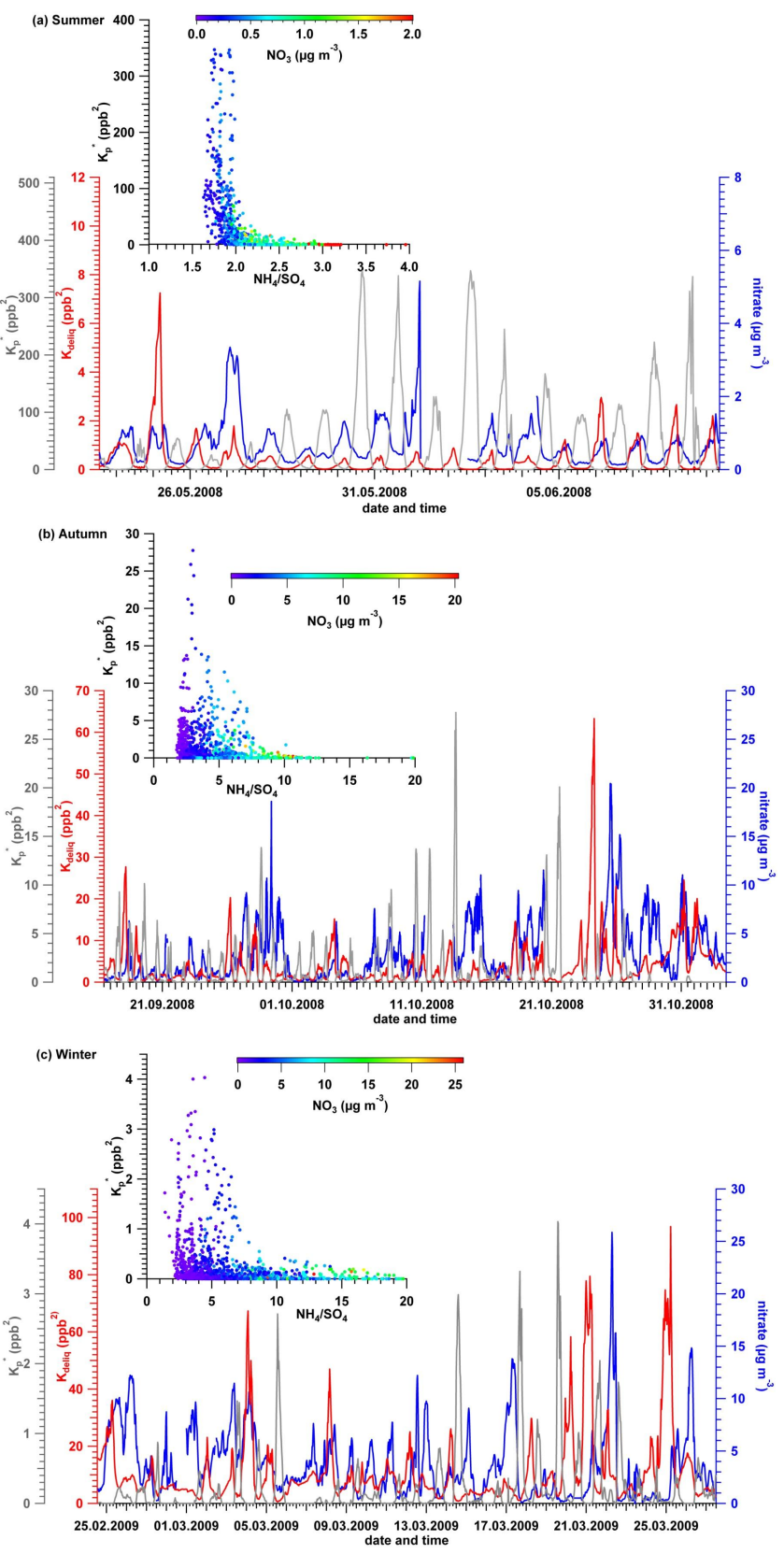

Fig. 8. Time series of the nitrate concentration and the theoretical equilibrium constants $\left(K_{p}^{*}(T)\right.$ and $\left.K_{\text {deliq }}(T)\right)$ for pure ammonium nitrate during the three measurement periods ((a) summer, (b) autumn and (c) Winter). The insert scatter plots is the relation between $K_{p}^{*}(T)$ and the particulate ammonium to sulfate ratio colored by the nitrate concentration.

anti-correlate to $K_{p}^{*}$ for all seasons. The decrease of nitrate concentration when $K_{p}^{*}$ increases agrees with an increased conversion of particle phase ammonium nitrate into gas phase $\mathrm{HNO}_{3}$ and $\mathrm{NH}_{3}$ during daytime.
The equilibrium constant of Reaction (R2) could also be expressed as describing the formation of ammonium nitrate on deliquescent particles $\left(K_{\text {deliq }}\right)$ instead of describing its dissociation $\left(K_{p}^{*}\right) . K_{\text {deliq }}$ can be calculated as follows (Sun et al., 2011):

$$
\begin{aligned}
K_{\text {deliq }}(T)= & K(298) \exp \left[\mathrm{a}\left(\frac{298}{T}-1\right)+\mathrm{b}\left(1+\ln \frac{298}{\mathrm{~T}}\right)-\frac{298}{\mathrm{~T}}\right] \\
& \times 10^{-18}
\end{aligned}
$$

With $K(298)=3.35 \times 10^{16} \mathrm{~atm}^{-2}, \mathrm{a}=75.11, \mathrm{~b}=-13.5$ and, $10^{-18}$ a conversion factor that provides the same unit as $K_{p}^{*}$. A similar approach is used to describe nitrate concentration in the ISORROPIA model by Fountoukis and Nenes (2007) and Nenes et al. (1998).

As for $K_{p}^{*}$, the time series and the diurnal variations of $\mathrm{K}_{\text {deliq }}$ are presented in Figs. 7 and 8. Because $K_{\text {deliq }}$ describes the reverse mechanism of $K_{p}^{*}$, the diurnal variation of $K_{\text {deliq }}$ correlates with diurnal changes on nitrate concentrations during day. The same observations was made by Zhang et al. (2005a) and Sun et al. (2011) who also considered the presence of deliquescent particles only.

The fact that diurnal profiles of nitrate follow very well their thermodynamic properties $\left(K_{p}^{*}\right.$ and/or $\left.K_{\text {deliq }}\right)$ suggests an important evaporation of ammonium nitrate during the day and a condensation process on pre-existing particles during the night. As previously shown for the organic fragment $m / z, 43$, the nitrate size distribution between the summers's day and night is presented in Fig. 5. As $m / z$ 43, a typical nitrate size distribution peaks around $300 \mathrm{~nm}$ during day and shows a double mode with a first maximum at $120 \mathrm{~nm}$ and a second one around $300 \mathrm{~nm}$ during night. The similarity of the $m / z, 43$ and the nitrate size distribution is consistent with a nighttime condensation of nitrate on pre-existing particles.

\subsubsection{Discussion of the factors influencing the nitrate diurnal profiles}

The philosophy of our approach was based on a comparison between measured nitrate concentration and theoretical equilibrium constants for pure ammonium nitrate $\left(K_{p}^{*}\right.$ and $\left.K_{\text {deliq }}\right)$. This is a simple theoretical approach, considering only that ammonium nitrate is externally mixed, which is generally not the case, and that the gas-to-particle equilibrium is reached instantaneously. While Pio et al. (1992) observed a kinetic effect on the ammonium nitrate formation, other studies about fine particles have shown that the instantaneous equilibrium assumption is applicable (Takahama et al., 2004; Yu et al., 2005b) in agreement with our estimation. However, this does not seem to be the case for larger particles (Meng and Seinfeld, 1996). Regarding the different diurnal profiles (Fig. 7), a systematic discrepancy between nitrate concentration and equilibrium constants $K_{p}^{*}$ and $K_{\text {deliq }}$ profiles can be observed early in the morning directly after dawn. This may suggest a possible kinetic effect on the ammonium 
nitrate formation (Pio et al., 1992). However, due to the limiting number of gas phase species measurements available in this study, it is highly speculative to clearly conclude on such effect. Indeed, the influences of gas phase reactivity at the transition time between night and day, like HONO photolysis for example, and/or influence of the dynamics of the atmosphere have also to be considered.

The formation of ammonium nitrate also depends on the aerosol chemical composition as well as on the available ammonia in the gas phase. Indeed, ammonia is preferentially scavenged by sulfuric acid. Only when sulfate is neutralized, the excess of ammonia leads to the formation of ammonium nitrate (Seinfeld and Pandis, 2006). For all sampling periods, the ratio of total ammonium $\left(\mathrm{TA}=\mathrm{NH}_{3}+\mathrm{NH}_{4}^{+}\right)$to total sulfate $\left(\mathrm{TS}=\mathrm{SO}_{2}+\mathrm{SO}_{4}^{2-}\right.$ ) was calculated. Most of the time, the ratio was larger than 2 corresponding to an excess of ammonia. At this level, the formation of ammonium nitrate is therefore possible. Moreover, the particulate ammonium to sulfate ratio was also estimated and the resulting averaged ratio of each campaign was larger than 2 which is interpreted as corresponding to ammonium sulfate formation (inserts in Fig. 8). The ammonium to sulfate ratio is in agreement with the neutralization state of the particles previously discussed (see Sect. 4.1). However, during a few afternoons in summer, the ammonium to sulfate ratio was slightly below 2 (down to 1.6). This may indicate a possible small amount of ammonium bisulfate. These periods also coincided with important new particle formation events. Figure 8 shows the relationship between $K_{p}^{*}$ and the ammonium to sulfate ratio. The highest $K_{p}^{*}$ values happened during a low ammonium to sulfate ratio and a lower nitrate concentration. The relationship between nitrate formation and the ammonium to sulfate ratio was very well pronounced during the summer campaign, a period of strong photochemistry and sulfuric acid formation. This suggests a possible enhancement of nitrate depletion during day by larger ammonia consumption to sulfuric acid neutralization during summer. The time series of nitrate, $K_{p}^{*}$ and $K_{\text {deliq }}$ for the different seasons are also presented in Fig. 8. Most of the time nitrate concentrations followed $K_{p}^{*}$ and $\mathrm{K}_{\text {deliq }}$ as previously described in Fig. 7. However, during some few events, nitrate concentration appears to not be connected to its equilibrium rate constants. For example, during these periods, an increase of the nitrate concentration can be observed while its thermodynamic equilibrium rate constant predicts a lower concentration (e.g. on 14 October 2008 and 25 February 2009). These periods have to be related to short influence of local sources and/or fast changes in air mass origin.

In Europe, the formation of ammonium nitrate is considered to be limited by the formation of $\mathrm{HNO}_{3}$ (Sartelet et al., 2007). Unfortunately, no measurements of $\mathrm{HNO}_{3}$ were performed here. However, we can note that $\mathrm{HNO}_{3}$ does not react with $\mathrm{NH}_{3}$ only; it can also directly interact with the inorganic fraction of the aerosol, e.g. calcium carbonate, magnesium carbonate, and sodium chloride, leading to the formation of calcium nitrate, magnesium nitrate, and sodium nitrate, respectively. As previously mentioned in Sect. 4.1, contribution of $\mathrm{Na}^{+}, \mathrm{Ca}^{2+}, \mathrm{K}^{+}$and $\mathrm{Mg}^{2+}$ was negligible due to their low concentrations compare to $\mathrm{NH}_{4}^{+}, \mathrm{SO}_{4}^{2-}$ and $\mathrm{NO}_{3}^{-}$. Moreover, the presence of these cations on the coarse mode will limit the formation of ammonium nitrate in the fine mode. The comparison of the daily $\mathrm{PM}_{1}$ and $\mathrm{PM}_{2.5}$ inorganic composition during autumn and winter is presented in Table 3. Larger differences between fine and coarse modes are observed for sodium, chloride and nitrate. This is in agreement with the western air masses influence, reported during the autumn and winter campaigns, which included a certain maritime influence. Nevertheless, as Melpitz is located far away from the sea coast (minimum distance of approximately $400 \mathrm{~km}$ ); the sampling place is influenced by aged marine air masses rather than fresh ones. However, aging degree and for example conversion rate of $\mathrm{NaCl}$ to $\mathrm{NaNO}_{3}$ depends on the history of the air mass over the continent (crossing or not polluted area, RH ...). Hence, in some specific situations (e.g. marine air mass with little processing), coarse mode may contribute to trap $\mathrm{HNO}_{3}$ and therefore limit the ammonium nitrate formation. Additionally, gaseous $\mathrm{HNO}_{3}$ can also react with mineral dust particles (especially with calcium) as well as soil-derived particles (Metzger et al., 2006; Pakkanen et al., 1996). With only a daily time resolution, however, it is difficult to estimate the real contribution of the coarse mode on the nitrate equilibrium.

The importance of the dynamics of the atmosphere on the particulate nitrate concentration was demonstrated by Morino et al. (2006). However, no direct measurements of the mixed layer height were performed during these campaigns, except for 3 days at the end of the summer campaign, which is not enough to draw global conclusions. Considering only these 3 days, the decrease of nitrate concentration early in the morning goes together with the increase of the mixed layer height. Therefore, the mixed layer development should contribute to the observed decrease of nitrate concentration, while the stratification during night should support the increased concentration. Because of the low value of the dissociation equilibrium, the influence of the mixed layer height should be an important factor during winter.

Up to now, particulate ammonium nitrate formation has only been considered as resulting from the gas-to-particle partitioning. The reactivity of $\mathrm{NO}_{2}$ and $\mathrm{O}_{3}$ as well as $\mathrm{N}_{2} \mathrm{O}_{5}$ hydrolysis are more important during night and will be favored by the high $\mathrm{RH}$ (R3 to R5). In wet particles, $\mathrm{N}_{2} \mathrm{O}_{5}$ leads to the formation of $\mathrm{HNO}_{3}$ (R5) which can then be neutralized to ammonium nitrate by uptake of $\mathrm{NH}_{3}$ (R6).

$$
\begin{aligned}
& \mathrm{NO}_{2}+\mathrm{O}_{3} \longrightarrow \mathrm{NO}_{3}+\mathrm{O}_{2} \\
& \mathrm{NO}_{3}+\mathrm{NO}_{2} \longrightarrow \mathrm{N}_{2} \mathrm{O}_{5} \\
& \mathrm{~N}_{2} \mathrm{O}_{5}(\mathrm{~g})+\mathrm{H}_{2} \mathrm{O}(\mathrm{aq}) \longrightarrow 2 \mathrm{HNO}_{3}(\mathrm{aq})
\end{aligned}
$$



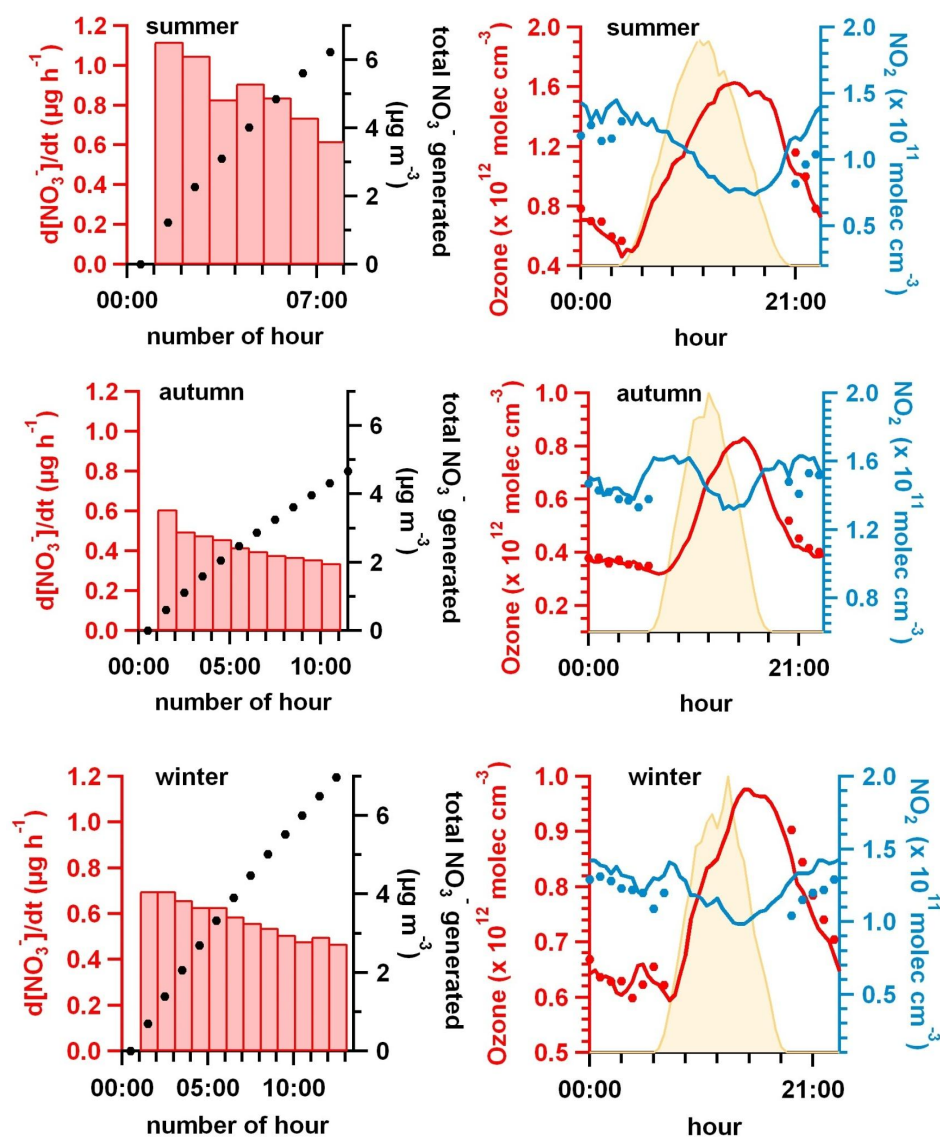

Fig. 9. Maximum nitrate formation rate and concentration expected from nighttime chemistry simulation for each season (left) and the comparison between the measured (line) and the simulated (dots) ozone and $\mathrm{NO}_{2}$ concentrations (right). The colored surface area on the right side corresponds to the solar radiation and can be used to distinguish nighttime from daytime chemistry.

$\mathrm{HNO}_{3}(\mathrm{aq})+\mathrm{NH}_{3}(\mathrm{~g}) \longrightarrow \mathrm{NH}_{4}^{+}(\mathrm{aq})+\mathrm{NO}_{3}^{-}(\mathrm{aq})$

In order to evaluate the role of the night time chemistry on the nitrate formation, a simple zero-dimensional box model was developed based on Reactions (R3) and (R4) only and assuming a fully conversion of $\mathrm{N}_{2} \mathrm{O}_{5}$ via its heterogeneous reactivity R5 and R6. The model was run using GEPASI 3.30 downloaded from www.gepasi.org. The kinetic rate constants for Reactions (R3) and (R4) were taken from Li et al. (1993) and recalculated for each hour in order to considered changes of temperature over the nights. With this simulation, the maximum of particulate nitrate that could be expected from $\mathrm{N}_{2} \mathrm{O}_{5}$ decomposition ( $\mathrm{R} 5$ and $\mathrm{R} 6$ ) in one hour was calculated. To do this, we used the averaged diurnal concentrations of ozone and $\mathrm{NO}_{2}$ for each season and for each hour of the night and initialized our model to calculate the maximal nitrate concentration out of these ozone and $\mathrm{NO}_{2}$ concentrations. We concede that this model simplifies the nighttime chemistry mechanisms. For example, the reactivity of the nitrate radical with organic compounds and the wet deposition of $\mathrm{N}_{2} \mathrm{O}_{5}$ were not considered at this stage. The model simply assumed an instantaneous and complete transfer of $\mathrm{N}_{2} \mathrm{O}_{5}$ on particle. Therefore, this approach provides the maximum of particulate nitrate expected from nighttime chemistry rather than the real nitrate formation. The hourly production flux of particulate nitrate estimated during the night time of each season is presented in Fig. 9. The maximum of nitrate concentration produced during night via this pathway as well as the comparison of measured and calculated ozone and $\mathrm{NO}_{2}$ concentrations are also presented in Fig. 9. First of all, it can be seen that the Reactions (R3) and (R4) successfully reproduced the variations of ozone and $\mathrm{NO}_{2}$ night concentrations for each season. As expected, our simulated nitrate concentrations are higher than the measured concentrations for each season. However, a linear relationship between measured and estimated nitrate concentrations can be observed for each season (Fig. 10). This suggests that nighttime chemistry may be a significant source of ammonium nitrate, especially during winter. The importance of the nitrate radical and $\mathrm{N}_{2} \mathrm{O}_{5}$ nighttime chemistry was previously reported by several authors (e.g. Brown et al., 2006, 
2003; Chang et al., 2011; Geyer et al., 2001; McLaren et al., 2004). For example, Li et al. (1993) demonstrated that nitrate radical and $\mathrm{N}_{2} \mathrm{O}_{5}$ nighttime chemistry can contribute as much as $80 \%$ and $10 \%$ to the night time nitrate production respectively, in a Canadian rural place. Therefore, the authors concluded that in their conditions, Reaction (R2) represented a minor source. The results of our simple model shown that the maximum expected nitrate concentration is slightly higher in winter than during summer nights while the calculated nitrate formation rate is larger in summer (ranging from 1.1 to $\left.0.6 \mu \mathrm{g} \mathrm{h}^{-1}\right)$ than winter $\left(0.7\right.$ to $\left.0.5 \mu \mathrm{gh}^{-1}\right)$. The increase of nitrate concentration measured during the night was lower in summer $\left(\Delta \mathrm{NO}_{3}^{-}=0.7 \mu \mathrm{g} \mathrm{m}^{-3}\right)$, increased in autumn $\left(\Delta \mathrm{NO}_{3}^{-}=1.6 \mu \mathrm{g} \mathrm{m}^{-3}\right)$ and reached a maximum in winter $\left(\Delta \mathrm{NO}_{3}^{-}=3.6 \mu \mathrm{g} \mathrm{m}^{-3}\right)$. Comparing the simulation results and the measured concentrations, the slope of the relationship between measured and simulated nitrate concentrations increased from summer $(0.11)$ to winter $(0.47)$ (Fig. 10). Regarding only the results model, these suggest that even if nighttime chemistry has a larger theoretical contribution on the nitrate concentration during summer nighttime, the small increase of nitrate concentration can be interpreted as a limited contribution of the nighttime chemistry during summer. On the other hand, the nighttime chemistry seems to be more important during winter time which is in agreement with Chang et al. (2011).

As discussed above, different factors directly contribute to influence the particulate nitrate concentration and two of them seemed to have a special importance during our measurements at the research station Melpitz: the thermodynamic properties of ammonium nitrate and the nitrate formation by nighttime chemistry. Therefore these two parameters have to be considered together. While the nighttime chemistry seems to represent a larger potential source of nitrate in summer than winter, its direct contribution to the particulate ammonium nitrate is limited by the low value of the $K_{\text {deliq }}$ (approx. 10 times lower in summer than winter). Therefore, the produced nighttime nitrate should be released more into the gas phase during summer than winter nights. Additionally, due to the similar expected nitrate formation, the differences in $K_{\text {deliq }}$ (factor 10) as well as $\Delta \mathrm{NO}_{3}^{-}$(factor 5) between winter and summer suggest a larger influence of the thermodynamic equilibrium during warmer periods (summer) in agreement with the observed condensation of semivolatile organic compounds, and a larger influence of nighttime chemistry during dark and cold periods (winter). Our results highlight the strong influence of the factor "season" on the particulate nitrate formation during the night for the conditions of this study at Melpitz which are representative for the central European aerosol. Nevertheless, these results are based on two simple and theoretical assumptions considering pure ammonia, nitric acid and water system for the thermodynamic factors and a complete conversion of $\mathrm{N}_{2} \mathrm{O}_{5}$ into ammonium nitrate for the nighttime chemistry. More mea-
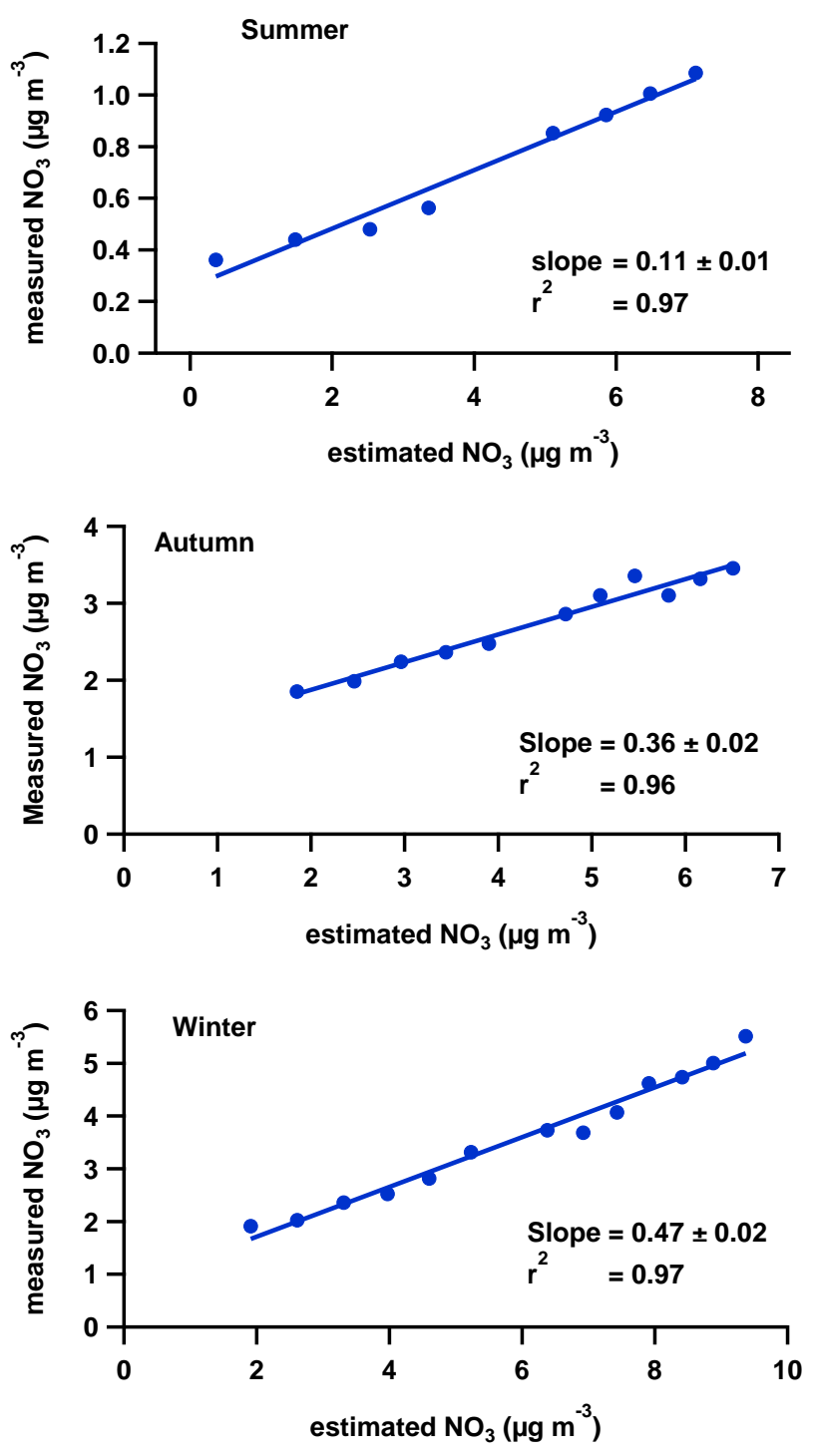

Fig. 10. The comparison of measured and simulated nitrate concentrations for each season.

surements are needed to better quantify the real influence of these two parameters and their interactions.

\section{Conclusions}

The comparison of AMS measurements at the Central European IfT research station Melpitz (Germany) throughout a year showed a large contribution of organics (59\%) and sulfate $(17.5 \%)$ to total particle mass concentration during the summer period, whereas the winter period was characterized by a large contribution of nitrate $(34.4 \%)$. In addition, the $O M / O C$ ratio was slightly influenced by the season with values being higher during summer (1.73) than winter time (1.64). Even if at first glance, diurnal variations of organic 
and nitrate show similarities over the year, some important changes and influences of local meteorology and chemical reactivity could be observed.

The diminution of the total OA concentration during day time, which was mainly observed during the warm seasons, can be linked to the dilution effect of increasing mixed layer height. Significant photochemical aging and/or a condensation of low volatile compounds, resulting from VOC ozonolysis, were observed during day time in the summer period, corresponding to the increase of $O M / O C$ (from 1.65 during night time to 1.80 during day time) and OSc (from -0.66 to -0.4). The impact of photochemistry and temperature became less important during the cold seasons, therefore, only a small increase of $O M / O C$ (from 1.60 to 1.67) and OSc (from -0.8 to -0.7 ) was observed in winter. It is thus possible to conclude that the winter OA mainly corresponded to long range transport of particles whereas summer OA was basically influenced by the regional photochemistry. Moreover, the mixed layer height should also have a significant contribution to the diurnal profiles of the organics; however, due to the lack of systematic measurements during the different campaigns, it is relatively difficult to estimate its influence. These results confirm the importance of the factor "season" in order to compare the OA compositions in meta-analyses of the worldwide particle composition (e.g. Ng et al., 2010; Zhang et al., 2007a) and the contribution of local chemistry to particle chemical composition.

During our measurements, the ratio TA/TS $>2$ indicated an excess of ammonia. Therefore, as already suggested by Sartelet et al. (2007), the formation rate of $\mathrm{HNO}_{3}$ certainly represents a very important limiting factor for the gas-toparticle phase equilibrium of ammonium nitrate. However, due to the absence of $\mathrm{HNO}_{3}$ measurements, we cannot prove this. Our results suggest that during daytime, nitrate concentrations systematically decrease because of ammonium nitrate dissociation. During the night, the increase of the nitrate concentration was more important in winter $\left(\Delta \mathrm{NO}_{3}^{-}=\right.$ $\left.3.6 \mu \mathrm{g} \mathrm{m}^{-3}\right)$ than in summer $\left(\Delta \mathrm{NO}_{3}^{-}=0.7 \mu \mathrm{g} \mathrm{m}^{-3}\right)$. Although the condensation of $\mathrm{HNO}_{3}$ and $\mathrm{NH}_{3}$ on deliquescent particles, leading to the formation of ammonium nitrate, seems to be important during nights of warmer seasons, the influence of the nitrate radical and $\mathrm{N}_{2} \mathrm{O}_{5}$ nighttime chemistry becomes the dominant source of ammonium nitrate during colder and darker seasons. Our results emphasize the strong influence of the season on the factors driving the nitrate formation during night. Nevertheless, more investigations are necessary to better quantify the real influence of these two parameters. However, as for the organics, the influence of the dynamics of the atmosphere on the nitrate concentration has also to be considered and systematic measurements at the station are required. Finally, consequently to the decrease of $\mathrm{SO}_{2}$ emissions, and therefore particles sulfate mass concentration (Spindler et al., 2004), ammonium nitrate represents an important compound for local air quality (Silva et al., 2007; Yin and Harrison, 2008). Our results confirm this and underline the need for more systematic measurements of particulate chemical composition and gas phase HONO, $\mathrm{HNO}_{3}$ and $\mathrm{NH}_{3}$ in order to improve the knowledge of the nitrate chemistry and to evaluate its atmospheric impact. Further investigations on the particulate nitrate behavior will be performed by combining the AMS measurements with other on-line instrumentations like a Monitor for Aerosols and Gases in ambient Air (MARGA, Applikon Analytical, NL, ten Brink et al., 2007). This should help us to simultaneously investigate the gas-to-particle partitioning and the particle size influence on the nitrate equilibrium.

\section{Supplementary material related to this article is available online at: http://www.atmos-chem-phys.net/11/12579/2011/ acp-11-12579-2011-supplement.pdf.}

Acknowledgements. We gratefully acknowledge support from the Umweltbundesamt (UBA) grants, no. 35101031 and no. 35101 038, UFOPLAN contract 370343200 (Title "Erfassung des Zahl feiner und ultrafeiner Partikel in der Außenluft") and the European Integrated Project on Aerosol Cloud Climate and Air Quality Interactions (EUCAARI). We appreciate extensive instrumental support by Joachim Grüner and Thomas Tuch (IfT) at the Melpitz field site.

Edited by: D. Simpson

\section{References}

Aiken, A. C., DeCarlo, P. F., and Jimenez, J. L.: Elemental analysis of organic species with electron ionization highresolution mass spectrometry, Anal. Chem., 79, 8350-8358, doi:10.1021/ac071150w, 2007.

Aiken, A. C., Decarlo, P. F., Kroll, J. H., Worsnop, D. R., Huffman, J. A., Docherty, K. S., Ulbrich, I. M., Mohr, C., Kimmel, J. R., Sueper, D., Sun, Y., Zhang, Q., Trimborn, A., Northway, M., Ziemann, P. J., Canagaratna, M. R., Onasch, T. B., Alfarra, M. R., Prevot, A. S. H., Dommen, J., Duplissy, J., Metzger, A., Baltensperger, U., and Jimenez, J. L.: $O / C$ and $O M / O C$ ratios of primary, secondary, and ambient organic aerosols with highresolution time-of-flight aerosol mass spectrometry, Environ. Sci. Technol., 42, 4478-4485, doi:10.1021/es703009q, 2008.

Aiken, A. C., Salcedo, D., Cubison, M. J., Huffman, J. A., DeCarlo, P. F., Ulbrich, I. M., Docherty, K. S., Sueper, D., Kimmel, J. R., Worsnop, D. R., Trimborn, A., Northway, M., Stone, E. A., Schauer, J. J., Volkamer, R. M., Fortner, E., de Foy, B., Wang, J., Laskin, A., Shutthanandan, V., Zheng, J., Zhang, R., Gaffney, J., Marley, N. A., Paredes-Miranda, G., Arnott, W. P., Molina, L. T., Sosa, G., and Jimenez, J. L.: Mexico City aerosol analysis during MILAGRO using high resolution aerosol mass spectrometry at the urban supersite (T0) - Part 1: Fine particle composition and organic source apportionment, Atmos. Chem. Phys., 9, 66336653, doi:10.5194/acp-9-6633-2009, 2009. 
Alfarra, M. R., Prevot, A. S. H., Szidat, S., Sandradewi, J., Weimer, S., Lanz, V. A., Schreiber, D., Mohr, M., and Baltensperger, U.: Identification of the mass spectral signature of organic aerosols from wood burning emissions, Environ. Sci. Technol., 41, 57705777, doi:10.1021/Es062289b, 2007.

Alfarra, R. M., Coe, H., Allan, J. D., Bower, K. N., Boudries, H., Canagaratna, M. R., Jimenez, J. L., Jayne, J. T., Garforth, A. A., Li, S.-m., and Worsnop, D. R.: Characterization of urban and rural organic particulate in the Lower Fraser Valley using two Aerodyne Aerosol Mass Spectrometers, Atmos. Environ., 38, 5745-5758, doi:10.1016/j.atmosenv.2004.01.054, 2004.

Allan, J. D., Williams, P. I., Morgan, W. T., Martin, C. L., Flynn, M. J., Lee, J., Nemitz, E., Phillips, G. J., Gallagher, M. W., and Coe, H.: Contributions from transport, solid fuel burning and cooking to primary organic aerosols in two UK cities, Atmos. Chem. Phys., 10, 647-668, doi:10.5194/acp-10-647-2010, 2010.

Ansari, A. S. and Pandis, S. N.: The effect of metastable equilibrium states on the partitioning of nitrate between the gas and aerosol phases, Atmos. Environ., 34, 157-168, 2000.

Asmi, A., Wiedensohler, A., Laj, P., Fjaeraa, A.-M., Sellegri, K., Birmili, W., Weingartner, E., Baltensperger, U., Zdimal, V., Zikova, N., Putaud, J.-P., Marinoni, A., Tunved, P., Hansson, H.C., Fiebig, M., Kiveks, N., Lihavainen, H., Asmi, E., Ulevicius, V., Aalto, P. P., Swietlicki, E., Kristensson, A., Mihalopoulos, N., Kalivitis, N., Kalapov, I., Kiss, G., de Leeuw, G., Henzing, B., Harrison, R. M., Beddows, D., O’Dowd, C., Jennings, S. G., Flentje, H., Weinhold, K., Meinhardt, F., Ries, L., and Kulmala, M.: Number size distributions and seasonality of submicron particles in Europe 2008-2009, Atmos. Chem. Phys., 11, 5505-5538, doi:10.5194/acp-11-5505-2011, 2011.

Bae, M.-S., Demerjian, K. L., and Schwab, J. J.: Seasonal estimation of organic mass to organic carbon in $\mathrm{PM}_{2.5}$ at rural and urban locations in New York state, Atmos. Environ., 40, 74677479, 2006.

Bao, L., Matsumoto, M., Kubota, T., Kazuhiko, S., Wang, Q., and Sakamoto, K.: Gas/particle partitioning of low-moleculareweight dicarboxylic acids at a suburban site in Saitama, Japan, Atmos. Environ., in press, doi:10.1016/j.atmosenv.2009.09.014, 2009.

Bauer, S. E., Koch, D., Unger, N., Metzger, S. M., Shindell, D. T., and Streets, D. G.: Nitrate aerosols today and in 2030: a global simulation including aerosols and tropospheric ozone, Atmos. Chem. Phys., 7, 5043-5059, doi:10.5194/acp-7-5043-2007, 2007.

Berresheim, H., Elste, T., Plass-Dulmer, C., Eisele, F. L., and Tanner, D. J.: Chemical ionization mass spectrometer for longterm measurements of atmospheric $\mathrm{OH}$ and $\mathrm{H}_{2} \mathrm{SO}_{4}$, Int. J. Mass. Spectrom., 202, 91-109, 2000.

Bessagnet, B., Seigneur, C., and Menut, L.: Impact of dry deposition of semi-volatile organic compounds on secondary organic aerosols, Atmos. Environ., 44, 1781-1787, doi:10.1016/j.atmosenv.2010.01.027, 2010.

Birmili, W., Stratmann, F., and Wiedensohler, A.: Design of a DMA-based size spectrometer for a large particle size range and stable operation, J. Aerosol Sci., 30, 549-553, 1999.

Birmili, W., Wiedensohler, A., Heintzenberg, J., and Lehmann, K.: Atmospheric particle number size distribution in central Europe: Statistical relations to air masses and meteorology, J. Geophys. Res.-Atmos., 106, 32005-32018, 2001.
Birmili, W., Schepanski, K., Ansmann, A., Spindler, G., Tegen, I., Wehner, B., Nowak, A., Reimer, E., Mattis, I., Mller, K., Brggemann, E., Gnauk, T., Herrmann, H., Wiedensohler, A., Althausen, D., Schladitz, A., Tuch, T., and Lschau, G.: A case of extreme particulate matter concentrations over Central Europe caused by dust emitted over the southern Ukraine, Atmos. Chem. Phys., 8, 997-1016, doi:10.5194/acp-8-997-2008, 2008.

Birmili, W., Weinhold, K., Nordmann, S., Wiedensohler, A., Spindler, G., Müller, K., Herrmann, H., Gnauk, T., Pitz, M., Cyrys, J., Flentje, H., Nickel, C., Kuhlbusch, T. A. J., and Löschau, G.: Atmospheric aerosol measurements in the German Ultrafine Aerosol Network (GUAN): Part 1 - soot and particle number size distribution, Gefahrst. Reinh. Luft., 69, 137-145, 2009.

Bohlmann, N., Meissner, R., Bernsdorf, S., Bohme, F., Russow, R., and Wegener, U.: Studies of atmospheric nitrogen deposition in a mire of the German National Park Hochharz Mountains using two different methods, Water Air Soil Poll., 168, 17-32, doi:10.1007/s11270-005-0587-0, 2005.

Bohn, B., Corlett, G. K., Gillmann, M., Sanghavi, S., Stange, G., Tensing, E., Vrekoussis, M., Bloss, W. J., Clapp, L. J., Kortner, M., Dorn, H.-P., Monks, P. S., Platt, U., Plass-Dülmer, C., Mihalopoulos, N., Heard, D. E., Clemitshaw, K. C., Meixner, F. X., Prevot, A. S. H., and Schmitt, R.: Photolysis frequency measurement techniques: results of a comparison within the ACCENT project, Atmos. Chem. Phys., 8, 5373-5391, doi:10.5194/acp-85373-2008, 2008.

Brown, S. S., Stark, H., Ryerson, T. B., Williams, E. J., Nicks, D. K., Trainer, M., Fehsenfeld, F. C., and Ravishankara, A. R.: Nitrogen oxides in the nocturnal boundary layer: Simultaneous in situ measurements of $\mathrm{NO}_{3}, \mathrm{~N}_{2} \mathrm{O}_{5}, \mathrm{NO}_{2}, \mathrm{NO}$, and $\mathrm{O}_{3}$, J. Geophys. Res.-Atmosp., 108, 4299, doi:10.1029/2002JD002917, 2003.

Brown, S. S., Neuman, J. A., Ryerson, T. B., Trainer, M., Dube, W. P., Holloway, J. S., Warneke, C., de Gouw, J. A., Donnelly, S. G., Atlas, E., Matthew, B., Middlebrook, A. M., Peltier, R., Weber, R. J., Stohl, A., Meagher, J. F., Fehsenfeld, F. C., and Ravishankara, A. R.: Nocturnal odd-oxygen budget and its implications for ozone loss in the lower troposphere, Geophys. Res. Lett., 33, L08801, doi:10.1029/2006GL025900, 2006.

Brüggemann, E. and Rolle, W.: Changes of some components of precipitation in East Germany after the reunification, Water Air Soil Poll., 107, 1-23, 1998.

Canagaratna, M. R., Jayne, J. T., Ghertner, D. A., Herndon, S., Shi, Q., Jimenez, J. L., Silva, P. J., Williams, P. I., Lanni, T., Drewnick, F., Demerjian, K. L., and Kolb, C. E.: Chase studies of particulate emissions from in-use New York city vehicles, Aerosol Sci. Technol., 38, 555-573, 2004.

Canagaratna, M. R., Jayne, J. T., Jimenez, J. L., Allan, J. D., Alfarra, M. R., Zhang, Q., Onasch, T. B., Drewnick, F., Coe, H., Middlebrook, A., Delia, A., Williams, L. R., Trimborn, A. M., Northway, M. J., Decarlo, P. F., Kolb, C. E., Davidovits, P., and Worsnop, D. R.: Chemical and microphysical characterization of ambient aerosols with the Aerodyne aerosol mass spectrometer, Mass Spectrom. Rev., 26, 185-222, doi:10.1002/mas.20115, 2007.

Chan, T. W., Huang, L., Leaitch, W. R., Sharma, S., Brook, J. R., Slowik, J. G., Abbatt, J. P. D., Brickell, P. C., Liggio, J., Li, S.M., and Moosmller, H.: Observations of OM/OC and specific 
attenuation coefficients (SAC) in ambient fine PM at a rural site in central Ontario, Canada, Atmos. Chem. Phys., 10, 2393-2411, doi:10.5194/acp-10-2393-2010, 2010.

Chang, W. L., Bhave, P. V., Brown, S. S., Riemer, N., Stutz, J., and Dabdub, D.: Heterogeneous Atmospheric Chemistry, Ambient Measurements, and Model Calculations of $\mathrm{N}_{2} \mathrm{O}_{5}$ : A Review, Aerosol Sci. Technol., 45, 665-695, doi:10.1080/02786826.2010.551672, 2011.

Cubison, M. J., Ortega, A. M., Hayes, P. L., Farmer, D. K., Day, D., Lechner, M. J., Brune, W. H., Apel, E., Diskin, G. S., Fisher, J. A., Fuelberg, H. E., Hecobian, A., Knapp, D. J., Mikoviny, T., Riemer, D., Sachse, G. W., Sessions, W., Weber, R. J., Weinheimer, A. J., Wisthaler, A., and Jimenez, J. L.: Effects of aging on organic aerosol from open biomass burning smoke in aircraft and lab studies, Atmos. Chem. Phys. Discuss., 11, 12103-12140, doi:10.5194/acpd-11-12103-2011, 2011.

Dall'Osto, M., Ceburnis, D., Martucci, G., Bialek, J., Dupuy, R., Jennings, S. G., Berresheim, H., Wenger, J. C., Sodeau, J. R., Healy, R. M., Facchini, M. C., Rinaldi, M., Giulianelli, L., Finessi, E., Worsnop, D., and O'Dowd, C. D.: Aerosol properties associated with air masses arriving into the North East Atlantic during the 2008 Mace Head EUCAARI intensive observing period: an overview, Atmos. Chem. Phys. Discuss., 9, 2626526328, doi:10.5194/acpd-9-26265-2009, 2009.

DeCarlo, P. F., Kimmel, J. R., Trimborn, A., Northway, M. J., Jayne, J. T., Aiken, A. C., Gonin, M., Fuhrer, K., Horvath, T., Docherty, K. S., Worsnop, D. R., and Jimenez, J. L.: Field-deployable, high-resolution, time-of-flight aerosol mass spectrometer, Anal. Chem., 78, 8281-8289, doi:10.1021/ac061249n, 2006.

Dunlea, E. J., DeCarlo, P. F., Aiken, A. C., Kimmel, J. R., Peltier, R. E., Weber, R. J., Tomlison, J., Collins, D. R., Shinozuka, Y., McNaughton, C. S., Howell, S. G., Clarke, A. D., Emmons, L. K., Apel, E. C., Pfister, G. G., van Donkelaar, A., Martin, R. V., Millet, D. B., Heald, C. L., and Jimenez, J. L.: Evolution of Asian aerosols during transpacific transport in INTEX-B, Atmos. Chem. Phys. Discuss., 8, 15375-15461, doi:10.5194/acpd8-15375-2008, 2008.

Eatough, N. L., Mcgregor, S., Lewis, E. A., Eatough, D. J., Huang, A. A., and Ellis, E. C.: Comparison of 6 Denuder Methods and a Filter Pack for the Collection of Ambient $\mathrm{HNO}_{3}(\mathrm{~g}), \mathrm{HNO}_{2}(\mathrm{~g})$, and $\mathrm{SO}_{2}(\mathrm{~g})$ in the 1985 NSMC Study, Atmos. Environ., 22, 1601-1618, 1988.

Farmer, D. K., Matsunaga, A., Docherty, K. S., Surratt, J. D., Seinfeld, J. H., Ziemann, P. J., and Jimenez, J. L.: Response of an aerosol mass spectrometer to organonitrates and organosulfates and implications for atmospheric chemistry, P. Natl. Acad. Sci. USA , 107, 6670-6675, doi:10.1073/pnas.0912340107, 2010.

Fountoukis, C. and Nenes, A.: ISORROPIA II: a computationally efficient thermodynamic equilibrium model for $\mathrm{K}^{+}$. $\mathrm{Ca}^{2+}-\mathrm{Mg}^{2+}-\mathrm{NH}_{4}^{+}-\mathrm{Na}^{+}-\mathrm{SO}_{4}^{2-}-\mathrm{NO}_{3}^{-}-\mathrm{Cl}^{-}-\mathrm{H}_{2} \mathrm{O}$ aerosols, Atmos. Chem. Phys., 7, 4639-4659, doi:10.5194/acp-7-4639-2007, 2007.

Geyer, A., Alicke, B., Konrad, S., Schmitz, T., Stutz, J., and Platt, U.: Chemistry and oxidation capacity of the nitrate radical in the continental boundary layer near Berlin, J. Geophys. Res.-Atmos., 106, 8013-8025, 2001.

Gurjar, B. R., Jain, A., Sharma, A., Agarwal, A., Gupta, A., Nagpure, A. S., and Lelieveld, J.: Human health risks in megacities due to air pollution, Atmos. Environ., 44, 4606-4613, doi:10.1016/j.atmosenv.2010.08.011, 2010.

Healy, R. M., Hellebust, S., Kourtchev, I., Allanic, A., O'Connor, I. P., Bell, J. M., Healy, D. A., Sodeau, J. R., and Wenger, J. C.: Source apportionment of PM2.5 in Cork Harbour, Ireland using a combination of single particle mass spectrometry and quantitative semi-continuous measurements, Atmos. Chem. Phys., 10, 9593-9613, doi:10.5194/acp-10-9593-2010, 2010.

Hildebrandt, L., Engelhart, G. J., Mohr, C., Kostenidou, E., Lanz, V. A., Bougiatioti, A., DeCarlo, P. F., Prevot, A. S. H., Baltensperger, U., Mihalopoulos, N., Donahue, N. M., and Pandis, S. N.: Aged organic aerosol in the Eastern Mediterranean: the Finokalia Aerosol Measurement Experiment-2008, Atmos. Chem. Phys., 10, 4167-4186, doi:10.5194/acp-10-4167-2010, 2010.

Hock, N., Schneider, J., Borrmann, S., Rompp, A., Moortgat, G., Franze, T., Schauer, C., P "oschl, U., Plass-Dulmer, C., and Berresheim, H.: Rural continental aerosol properties and processes observed during the Hohenpeissenberg Aerosol Characterization Experiment (HAZE2002), Atmos. Chem. Phys., 8, 603-623, 2008,

http://www.atmos-chem-phys.net/8/603/2008/.

Holland, F., Hofzumahaus, A., Schafer, R., Kraus, A., and Patz, H. W.: Measurements of $\mathrm{OH}$ and $\mathrm{HO} 2$ radical concentrations and photolysis frequencies during BERLIOZ, J. Geophys. Res.Atmosp., 108, 8246, doi:10.1029/2001jd001393, 2003.

Huffman, J. A., Jayne, J. T., Drewnick, F., Aiken, A. C., Onasch, T., Worsnop, D. R., and Jimenez, J. L.: Design, modeling, optimization, and experimental tests of a particle beam width probe for the aerodyne aerosol mass spectrometer, Aerosol Sci. Technol., 39, 1143-1163, doi:10.1080/02786820500423782, 2005.

IPCC: Climate Change 2007: The physical science basis, 2007.

Jickells, T. D., An, Z. S., Andersen, K. K., Baker, A. R., Bergametti, G., Brooks, N., Cao, J. J., Boyd, P. W., Duce, R. A., Hunter, K. A., Kawahata, H., Kubilay, N., laRoche, J., Liss, P. S., Mahowald, N., Prospero, J. M., Ridgwell, A. J., Tegen, I., and Torres, R.: Global iron connections between desert dust, ocean biogeochemistry, and climate, Science, 308, 67-71, 2005.

Jimenez, J. L., Canagaratna, M. R., Donahue, N. M., Prevot, A. S. H., Zhang, Q., Kroll, J. H., DeCarlo, P. F., Allan, J. D., Coe, H., Ng, N. L., Aiken, A. C., Docherty, K. S., Ulbrich, I. M., Grieshop, A. P., Robinson, A. L., Duplissy, J., Smith, J. D., Wilson, K. R., Lanz, V. A., Hueglin, C., Sun, Y. L., Tian, J., Laaksonen, A., Raatikainen, T., Rautiainen, J., Vaattovaara, P., Ehn, M., Kulmala, M., Tomlinson, J. M., Collins, D. R., Cubison, M. J., E, Dunlea, J., Huffman, J. A., Onasch, T. B., Alfarra, M. R., Williams, P. I., Bower, K., Kondo, Y., Schneider, J., Drewnick, F., Borrmann, S., Weimer, S., Demerjian, K., Salcedo, D., Cottrell, L., Griffin, R., Takami, A., Miyoshi, T., Hatakeyama, S., Shimono, A., Sun, J. Y., Zhang, Y. M., Dzepina, K., Kimmel, J. R., Sueper, D., Jayne, J. T., Herndon, S. C., Trimborn, A. M., Williams, L. R., Wood, E. C., Middlebrook, A. M., Kolb, C. E., Baltensperger, U., and Worsnop, D. R.: Evolution of organic aerosols in the atmosphere, Science, 326, 1525-1529, doi:10.1126/science.1180353, 2009.

Keck, L. and Wittmaack, K.: Effect of filter type and temperature on volatilisation losses from ammonium salts in aerosol matter, Atmos. Environ., 39, 4093-4100, doi:10.1016/j.atmosenv.2005.03.029, 2005.

Kreidenweis, S. M., Petters, M. D., and DeMott, P. J.: Singleparameter estimates of aerosol water content, Environ. Res. Lett., 
3, 035002, doi:10.1088/1748-9326/3/3/035002, 2008.

Kroll, J. H., Donahue, N. M., Jimenez, J. L., Kessler, S. H., Canagaratna, M. R., Wilson, K. R., Altieri, K. E., Mazzoleni, L. R., Wozniak, A. S., Bluhm, H., Mysak, E. R., Smith, J. D., Kolb, C. E., and Worsnop, D. R.: Carbon oxidation state as a metric for describing the chemistry of atmospheric organic aerosol, Nature Chem., 3, 133-139, doi:10.1038/Nchem.948, 2011.

Kulmala, M., Asmi, A., Lappalainen, H. K., Carslaw, K. S., Pöschl, U., Baltensperger, U., Hov, Ø., Brenquier, J.-L., Pandis, S. N., Facchini, M. C., Hansson, H.-C., Wiedensohler, A., and O'Dowd, C. D.: Introduction: European Integrated Project on A erosol Cloud Climate and Air Quality interactions (EUCAARI) - integrating aerosol research from nano to global scales, Atmos. Chem. Phys., 9, 2825-2841, doi:10.5194/acp-9-2825-2009, 2009.

Li, S., Wang, T. J., Zhuang, B. L., and Han, Y.: Indirect radiative forcing and climatic effect of the anthropogenic nitrate aerosol on regional climate of China, Adv. Atmos. Sci., 26, 543-552, doi:10.1007/s00376-009-0543-9, 2009.

Li, S. M., Anlauf, K. G., and Wiebe, H. A.: Heterogeneous Nighttime Production and Deposition of Particle Nitrate at a Rural Site in North-America during Summer 1988, J. Geophys. Res.Atmos., 98, 5139-5157, 1993.

Liggio, J., Li, S. M., Vlasenko, A., Sjostedt, S., Chang, R., Shantz, N., Abbatt, J., Slowik, J. G., Bottenheim, J. W., Brickell, P. C., Stroud, C., and Leaitch, W. R.: Primary and secondary organic aerosols in urban air masses intercepted at a rural site, J. Geophys. Res.-Atmosp., 115, D21305, doi:10.1029/2010JD014426, 2010.

Martin, S. T., Schlenker, J. C., Malinowski, A., Hung, H. M., and Rudich, Y.: Crystallization of atmospheric sulfatenitrate-ammonium particles, Geophys. Res. Lett., 30, 2102, doi:10.1029/2003g1017930, 2003.

Matthew, B. M., Middlebrook, A. M., and Onasch, T. B.: Collection efficiencies in an Aerodyne Aerosol Mass Spectrometer as a function of particle phase for laboratory generated aerosols, Aerosol Sci. Technol., 42, 884-898, doi:10.1080/02786820802356797, 2008.

McLaren, R., Salmon, R. A., Liggio, J., Hayden, K. L., Anlauf, K. G., and Leaitch, W. R.: Nighttime chemistry at a rural site in the Lower Fraser Valley, Atmos. Environ., 38, 5837-5848, doi:10.1016/j.atmosenv.2004.03.074, 2004.

Meng, Z. Y. and Seinfeld, J. H.: Time scales to achieve atmospheric gas-aerosol equilibrium for volatile species, Atmos. Environ., 30, 2889-2900, 1996.

Metzger, S., Mihalopoulos, N., and Lelieveld, J.: Importance of mineral cations and organics in gas-aerosol partitioning of reactive nitrogen compounds: case study based on MINOS results, Atmos. Chem. Phys., 6, 2549-2567, 2006,

http://www.atmos-chem-phys.net/6/2549/2006/.

Morgan, W. T., Allan, J. D., Bower, K. N., Esselborn, M., Harris, B., Henzing, J. S., Highwood, E. J., Kiendler-Scharr, A., McMeeking, G. R., Mensah, A. A., Northway, M. J., Osborne, S., Williams, P. I., Krejci, R., and Coe, H.: Enhancement of the aerosol direct radiative effect by semi-volatile aerosol components: airborne measurements in North-Western Europe, Atmos. Chem. Phys., 10, 8151-8171, doi:10.5194/acp-10-8151-2010, 2010.

Morino, Y., Kondo, Y., Takegawa, N., Miyazaki, Y., Kita, K.,
Komazaki, Y., Fukuda, M., Miyakawa, T., Moteki, N., and Worsnop, D. R.: Partitioning of $\mathrm{HNO}_{3}$ and particulate nitrate over Tokyo: Effect of vertical mixing, J. Geophys. Res.-Atmosp., 111, D15215, doi:10.1029/2005jd006887, 2006.

Mozurkewich, M.: The Dissociation-Constant of AmmoniumNitrate and Its Dependence on Temperature, Relative-Humidity and Particle-Size, Atmos. Environ. A-Gen., 27, 261-270, 1993.

Nenes, A., Pandis, S. N., and Pilinis, C.: ISORROPIA: A new thermodynamic equilibrium model for multiphase multicomponent inorganic aerosols, Aquat. Geochem., 4, 123-152, 1998.

Ng, N. L., Canagaratna, M. R., Zhang, Q., Jimenez, J. L., Tian, J., Ulbrich, I. M., Kroll, J. H., Docherty, K. S., Chhabra, P. S., Bahreini, R., Murphy, S. M., Seinfeld, J. H., Hildebrandt, L., Donahue, N. M., DeCarlo, P. F., Lanz, V. A., Prevot, A. S. H., Dinar, E., Rudich, Y., and Worsnop, D. R.: Organic aerosol components observed in Northern Hemispheric datasets from Aerosol Mass Spectrometry, Atmos. Chem. Phys., 10, 46254641, doi:10.5194/acp-10-4625-2010, 2010.

Ostro, B., Feng, W. Y., Broadwin, R., Green, S., and Lipsett, M.: The effects of components of fine particulate air pollution on mortality in California: Results from CALFINE, Environ. Health Perspect., 115, 13-19, doi:10.1289/Ehp.9281, 2007.

Pakkanen, T. A., Kerminen, V. M., Hillamo, R. E., Makinen, M., Makela, T., and Virkkula, A.: Distribution of nitrate over seasalt and soil derived particles - Implications from a field study, J. Atmos. Chem., 24, 189-205, 1996.

Petzold, A. and Schonlinner, M.: Multi-angle absorption photometry - a new method for the measurement of aerosol light absorption and atmospheric black carbon, J. Aerosol Sci., 35, 421-441, doi:10.1016/j.jaerosci.2003.09.005, 2004.

Pio, C. A., Nunes, T. V., and Leal, R. M.: Kinetic and Thermodynamic Behavior of Volatile Ammonium-Compounds in Industrial and Marine Atmospheres, Atmos. Environ. A-Gen., 26, 505-512, 1992.

Pope, C. A.: Epidemiology of fine particulate air pollution and human health: Biologic mechanisms and who's at risk?, Environ. Health Perspect., 108, 713-723, 2000.

Putaud, J. P., Raes, F., Van Dingenen, R., Bruggemann, E., Facchini, M. C., Decesari, S., Fuzzi, S., Gehrig, R., Huglin, C., Laj, P., Lorbeer, G., Maenhaut, W., Mihalopoulos, N., Mulller, K., Querol, X., Rodriguez, S., Schneider, J., Spindler, G., ten Brink, H., Torseth, K., and Wiedensohler, A.: European aerosol phenomenology-2: chemical characteristics of particulate matter at kerbside, urban, rural and background sites in Europe, Atmos. Environ., 38, 2579-2595, doi:10.1016/j.atmosenv.2004.01.041, 2004.

Pye, H. O. T., Liao, H., Wu, S., Mickley, L. J., Jacob, D. J., Henze, D. K., and Seinfeld, J. H.: Effect of changes in climate and emissions on future sulfate-nitrate-ammonium aerosol levels in the United States, J. Geophys. Res.-Atmos., 114, D01205, doi:10.1029/2008jd010701, 2009.

Rohrer, F. and Berresheim, H.: Strong correlation between levels of tropospheric hydroxyl radicals and solar ultraviolet radiation, Nature, 442, 184-187, doi:10.1038/Nature04924, 2006.

Rupakheti, M., Leaitch, W. R., Lohmann, U., Hayden, K., Brickell, P., Lu, G., Li, S. M., Toom-Sauntry, D., Bottenheim, J. W., Brook, J. R., Vet, R., Jayne, J. T., and Worsnop, D. R.: An intensive study of the size and composition of submicron atmospheric aerosols at a rural site in Ontario, Canada, Aerosol Sci. Technol., 
39, 722-736, doi:10.1080/02786820500182420, 2005.

Sartelet, K. N., Debry, E., Fahey, K., Roustan, Y., Tombette, M., and Sportisse, B.: Simulation of aerosols and gasphase species over Europe with the POLYPHEMUS system: Part I - Model-to-data, Atmos. Environ., 41, 6116-6131, doi:10.1016/j.atmosenv.2007.04.024, 2007.

Schaap, M., Spindler, G., Schulz, M., Acker, K., Maenhaut, W., Berner, A., Wieprecht, W., Streit, N., Muller, K., Bruggemann, E., Chi, X., Putaud, J. P., Hitzenberger, R., Puxbaum, H., Baltensperger, U., and ten Brink, H.: Artefacts in the sampling of nitrate studied in the "INTERCOMP" campaigns of EUROTRAC-AEROSOL, Atmos. Environ., 38, 6487-6496, doi:10.1016/j.atmosenv.2004.08.026, 2004.

Schlosser, E., Brauers, T., Dorn, H. P., Fuchs, H., Haseler, R., Hofzumahaus, A., Holland, F., Wahner, A., Kanaya, Y., Kajii, Y., Miyamoto, K., Nishida, S., Watanabe, K., Yoshino, A., Kubistin, D., Martinez, M., Rudolf, M., Harder, H., Berresheim, H., Elste, T., Plass-Dulmer, C., Stange, G., and Schurath, U.: Technical Note: Formal blind intercomparison of $\mathrm{OH}$ measurements: results from the international campaign HOxComp, Atmos. Chem. Phys., 9, 7923-7948, doi:10.5194/acp-9-7923-2009, 2009.

Schneider, J., Weimer, S., Drewnick, F., Borrmann, S., Helas, G., Gwaze, P., Schmid, O., Andreae, M. O., and kirchner, U.: Mass spectrometric analysis and aerodynamic properties of various types of combustion-related aerosol particles, Int. J. Mass. Spectrom., 258, 37-49, doi:10.1016/j.ijms.2006.07.008, 2006.

Seinfeld, J. H. and Pandis, S. N.: Atmospheric Chemistry and Physics: from air pollution to climate change, John Wiley \& Sons, 2nd edn., New York, USA, 1248 pp., 2006.

Shaw, M. A. and Rood, M. J.: Measurement of the Crystallization Humidities of Ambient Aerosol-Particles, Atmos. Environ. AGen., 24, 1837-1841, 1990.

Silva, P. J., Vawdrey, E. L., Corbett, M., and Erupe, M.: Fine particle concentrations and composition during wintertime inversions in Logan, Utah, USA, Atmos. Environ., 41, 5410-5422, doi:10.1016/j.atmosenv.2007.02.016, 2007.

Singh, H. B., Brune, W. H., Crawford, J. H., Flocke, F., and Jacob, D. J.: Chemistry and transport of pollution over the Gulf of Mexico and the Pacific: spring 2006 INTEX-B campaign overview and first results, Atmos. Chem. Phys., 9, 2301-2318, 2009, http://www.atmos-chem-phys.net/9/2301/2009/.

Sjostedt, S. J., Slowik, J. G., Brook, J. R., Chang, R. Y.-W., Mihele, C., Stroud, C. A., Vlasenko, A., and Abbatt, J. P. D.: Diurnally resolved particulate and VOC measurements at a rural site: indication of significant biogenic secondary organic aerosol formation, Atmos. Chem. Phys., 11, 5745-5760, doi:10.5194/acp-115745-2011, 2011.

Slowik, J. G., Stroud, C., Bottenheim, J. W., Brickell, P. C., Chang, R. Y.-W., Liggio, J., Makar, P. A., Martin, R. V., Moran, M. D., Shantz, N. C., Sjostedt, S. J., van Donkelaar, A., Vlasenko, A., Wiebe, H. A., Xia, A. G., Zhang, J., Leaitch, W. R., and Abbatt, J. P. D.: Characterization of a large biogenic secondary organic aerosol event from eastern Canadian forests, Atmos. Chem. Phys., 10, 2825-2845, doi:10.5194/acp-10-2825-2010, 2010.

Spindler, G., Müller, K., Bruggemann, E., Gnauk, T., and Herrmann, H.: Long-term size-segregated characterization of $\mathrm{PM}_{10}$, $\mathrm{PM}_{2.5}$, and PM1 at the IfT research station Melpitz downwind of Leipzig (Germany) using high and low-volume filter samplers, Atmos. Environ., 38, 5333-5347, 2004.
Spindler, G., Bruggemann, E., Gnauk, T., Gruner, A., Muller, K., and Herrmann, H.: A four-year size-segregated characterization study of particles $\mathrm{PM}_{10}, \mathrm{PM}_{2.5}$ and $\mathrm{PM}_{1}$ depending on air mass origin at Melpitz, Atmos. Environ., 44, 164-173, doi:10.1016/j.atmosenv.2009.10.015, 2010.

Sun, J. Y., Zhang, Q., Canagaratna, M. R., Zhang, Y. M., Ng, N. L., Sun, Y. L., Jayne, J. T., Zhang, X. C., Zhang, X. Y., and Worsnop, D. R.: Highly time- and size-resolved characterization of submicron aerosol particles in Beijing using an Aerodyne Aerosol Mass Spectrometer, Atmos. Environ., 44, 131-140, doi:10.1016/j.atmosenv.2009.03.020, 2010.

Sun, Y. L., Zhang, Q., Schwab, J. J., Demerjian, K. L., Chen, W. N., Bae, M. S., Hung, H. M., Hogrefe, O., Frank, B., Rattigan, O. V., and Lin, Y. C.: Characterization of the sources and processes of organic and inorganic aerosols in New York city with a high-resolution time-of-flight aerosol mass apectrometer, Atmos. Chem. Phys., 11, 1581-1602, doi:10.5194/acp-11-15812011, 2011.

Takahama, S., Wittig, A. E., Vayenas, D. V., Davidson, C. I., and Pandis, S. N.: Modeling the diurnal variation of nitrate during the Pittsburgh Air Quality Study, J. Geophys. Res.-Atmos., 109, D16s06, doi:10.1029/2003jd004149, 2004.

Takegawa, N., Miyakawa, T., Kawamura, K., and Kondo, Y.: Contribution of selected dicarboxylic and $\omega$-Oxocarboxylic acids in ambient aerosol to the $\mathrm{m} / \mathrm{z}, 44$ signal of an Aerodyne aerosol mass spectrometer, Aerosol Sci. Technol., 41, 418-437, doi:10.1080/02786820701203215, 2007.

ten Brink, H., Otjes, R., Jongejan, P., and Slanina, S.: An instrument for semi-continuous monitoring of the size-distribution of nitrate, ammonium, sulphate and chloride in aerosol, Atmos. Environ., 41, 2768-2779, doi:10.1016/j.atmosenv.2006.11.041, 2007.

Topping, D. O., McFiggans, G. B., and Coe, H.: A curved multicomponent aerosol hygroscopicity model framework: Part 1 - Inorganic compounds, Atmos. Chem. Phys., 5, 1205-1222, doi:10.5194/acp-5-1205-2005, 2005.

Tuch, T. M., Haudek, A., Müller, T., Nowak, A., Wex, H., and Wiedensohler, A.: Design and performance of an automatic regenerating adsorption aerosol dryer for continuous operation at monitoring sites, Atmos. Meas. Tech., 2, 417-422, doi:10.5194/amt-2-417-2009, 2009.

Turpin, B. J. and Lim, H.-J.: Species contributions to $\mathrm{PM}_{2.5}$ mass concentrations: revisiting common assumptions for estimating organic mass, Aerosol Sci. Technol., 35, 302-610, doi:10.1080/02786820119445, 2001.

Volkamer, R., Ziemann, P. J., and Molina, M. J.: Secondary Organic Aerosol Formation from Acetylene $\left(\mathrm{C}_{2} \mathrm{H}_{2}\right)$ : seed effect on SOA yields due to organic photochemistry in the aerosol aqueous phase, Atmos. Chem. Phys., 9, 1907-1928, doi:10.5194/acp9-1907-2009, 2009.

Yin, J. X. and Harrison, R. M.: Pragmatic mass closure study for $\mathrm{PM}_{1.0}, \mathrm{PM}_{2.5}$ and $\mathrm{PM}_{10}$ at roadside, urban background and rural sites, Atmos. Environ., 42, 980-988, doi:0.1016/j.atmosenv.2007.10.005, 2008.

Yu, L. E., Shulman, M. L., Kopperud, R., and Hildemann, L. M.: Fine organic aerosols collected in a humid, rural location (Great Smoky Mountains, Tennessee, USA): Chemical and temporal characteristics, Atmos. Environ., 39, 6037-6050, doi:10.1016/j.atmosenv.2005.06.043, 2005a.

Yu, S. C., Dennis, R., Roselle, S., Nenes, A., Walker, J., 
Eder, B., Schere, K., Swall, J., and Robarge, W.: An assessment of the ability of three-dimensional air quality models with current thermodynamic equilibrium models to predict aerosol $\mathrm{NO}_{3}^{-}$, J. Geophys. Res.-Atmos., 110, D07s13, doi:10.1029/2004jd004718, 2005b.

Zhang, Q., Canagaratna, M. R., Jayne, J. T., Worsnop, D. R., and Jimenez, J. L.: Time- and size-resolved chemical composition of submicron particles in Pittsburgh: Implications for aerosol sources and processes, J. Geophys. Res.-Atmos., 110, D07S09, doi:10.1029/2004JD004649, 2005a.

Zhang, Q., Worsnop, D. R., Canagaratna, M. R., and Jimenez, J. L.: Hydrocarbon-like and oxygenated organic aerosols in Pittsburgh: insights into sources and processes of organic aerosols, Atmos. Chem. Phys., 5, 3289-3311, doi:10.5194/acp-5-32892005, 2005b.
Zhang, Q., Jimenez, J. L., Canagaratna, M. R., Allan, J., Coe, H., Ulbrich, I., Alfarra, M. R., Takami, A., Middlebrook, A., Sun, Y. L., Dzepina, K., Dunlea, E., Docherty, K., Decarlo, P. F., Salcedo, D., Onasch, T. B., Jayne, J. T., Miyoshi, T., Shimono, A., Hatakeyama, S., Takegawa, N., Kondo, Y., Schneider,J., Drewnick, F., Borrmann, S., Weimer, S., Demerjian, K. L., Williams, P., Bower, K. N., Bahreini, R., Cottrell, L., Griffin, R. J., Rautiainen, J., Sun, J. Y., Zhang, Y. H., and Worsnop, D. R.: Ubiquity and dominance of oxygenated species in organic aerosols in anthropogenically-influenced Northern Hemisphere midlatitudes, Geophys. Res. Lett., 34, L13801, doi:10.1029/2007GL029979, 2007a.

Zhang, Q., Jimenez, J. L., Worsnop, D. R., and Canagaratna, M. R.: A case study of urban particle acidity and its influence on secondary organic aerosol, Environ. Sci. Technol., 41, 3213-3219, doi:10.1021/es061812j, 2007b. 